\title{
Âlemin Ötesine Uzanan El: Mu‘tezile'nin Basra ve Bağdat Ekolleri Arasında Boşluk/Halâ Tartışmaları
}

\author{
Ahmet Mekin Kandemir"
}

\begin{abstract}
Öz: Kelâmda boşluk fikrini atomculuğun kabulüyle başlatmak mümkün olsa da konuyla ilgili asıl tartışmaların Yunan felsefî mirasının İslam dünyasına aktarılmasından sonra gün yüzüne çıktığı görülmektedir. Kelâm literatüründe, felsefî gelenekte olduğu gibi boşluğun iki türü olduğu kabul edilmiştir. Bunların ilki âlemin dışında/ötesinde bulunan haricî boşluktur (ekstra-kozmik), ki bu tarz bir boşluğun olup olmadığı problemi kelâm kaynaklarında "âlemin ötesine bakan kimse bir şey görebilir mi” veya "âlemin dışına elini uzatan kimsenin eli hareket eder mi” soruları etrafında tartışılmıştır. İkincisi ve kelâmcıların gündemini daha çok meşgul eden boşluk türü ise âlemin içinde ve cisimleri oluşturan atomların/cevherlerin arasında olduğu kabul edilen dâhilî boşluktur (inter-kozmik). Bu türden bir boşluğun olup olmadığı hususu kelâm kaynaklarında "iki cevherin, aralarında üçüncü bir cevher olmadan ayrık bir şekilde durması mümkün müdür?” sorusu etrafında tartışılmıştır. Özellikle âlem-içi boşluk konusunda Mu'tezile'nin Basra ve Bağdat ekolleri arasında yoğun tartışmalar yaşanmıştır. Bu tartışmalarda ortaya konan deliller İbn Metteveyh (V./ XI. yüzyılın ortaları) ve Ebû Reşîd en-Nîsâbûrî (V./XI. yüzyılın ortaları) tarafından orijinal halleriyle nakledilmiştir. Bu makalede iki ekol arasındaki bu tartışmalar ele alınmakta ve her iki ekolün kendi görüşlerini desteklemek için ortaya koyduğu teorik ve deneysel argümanlar, bunların felsefî kökenleri göz önünde bulundurularak değerlendirilmektedir.
\end{abstract}

Anahtar Kelimeler: Kelâm, Mu'tezile, Boşluk/halâ, Basra ekolü, Bağdat ekolü.

\begin{abstract}
We can find the origins of the notion of void in the Kalām tradition's recognition of atomism. However, the main debates on the subject appeared after the Greek philosophical heritage transitioned to the Islamic world in the $3^{\text {rd }}$ century of Hijra. The literature of Kaläm, just as in the metaphysical tradition, has two main types for this void being discussed. The first one is the external void (extracosmic) in which the cosmos floats. In the sources of Kalām, the question of whether such a type of void exists is debated around the questions of whether anyone who might look beyond the cosmos can see anything or whether someone who stretches their hand outside the cosmos can move it. The second type of void, which occupies more of the Mutakallimün agenda, is the internal void (intercosmic), assumed to be within the cosmos and between the body-forming atoms. This kind of void is discussed around the question of "Whether separating the two atoms is possible so that a third one can be inserted between them?" An ongoing discussion on the intercosmic void is found between the Bașran and Baghdād schools of Mu'tazilah. Ibn Mattawayh and al-Nissābūrī narrated the evidence presented in these discussions in their original form. The current essay discusses the debates between the two schools and assesses the theoretical and experimental arguments both schools present to justify their viewpoints considering their philosophical origins.
\end{abstract}

Keywords: Kalām, Mu'tazilah, Void, the Bașran School, the Baghdād School.

* Dr. Öğr. Üyesi, Ankara Sosyal Bilimler Üniversitesi İslami İlimler Fakültesi, Kelâm Anabilim Dalı. ahmetmekin@hotmail.com 


\section{GíRiş}

Âlemin içinde veya dışında boşluk olup olmadığı hususu Antik Yunan filozoflarından itibaren tartışılagelen bir problemdir. Sokrat öncesi dönemde boşluk konusu daha çok varlık-yokluk, birlik-çokluk ve hareket kavramlarıyla ilişkili olarak tartışılmıştır. Boşluğu ilk olarak kabul eden Pythagoras (MÖ 570-495), sayılardan oluşan bölünmez cisimleri ve boşluğu her şeyin ilkesi kabul etmiş ve boşluğun sonsuz bir nefes gibi tüm evrene yayıldığını savunmuştur. Onun tam sayılardan oluşan sisteminde boşluk, sayıları ve nesneleri birbirinden ayıran ve onların sınırını çizen bir varlık olarak tanımlanmıştır. Çünkü iki sayı veya nesnenin arasında bir boşluk olmadıkça bunların birbirinden bağımsız varlıklar olması mümkün görülmemiştir. Parmenides ( MÖ 600-500) ise varlığın bir ve sürekli olduğunu savunduğundan boşluğu reddetmiştir. Çünkü varlığın boşluk/yokluk tarafından kesintiye uğratılması onun tekliğini bozacaktır. Boşluğun olmadığı yerde hareketin de mümkün olamayacağını düşünen Parmenides, hareketi de tümüyle inkâr etmiştir. ${ }^{1}$ Parmenides'in öğrencisi Zenon (MÖ 490-430) ise boşluk düşüncesinin mantıksal çelişkilerini ortaya koymaya çalışmıştır. Ona göre eğer tüm oluşumlar bir uzamda meydana geliyorsa uzamın da bir uzam içinde olması gerekir. Başka bir deyişle eğer "boşluk" bir şeyse onun da bir şeyin içinde bulunması gerekir ve bu sonsuza dek bir kısırdöngüye sebep olur. Ayrıca bir nesnenin uzam içinde hareket edebilmesi için önce yarısını, yarısını kat edebilmesi için de önce onun yarısını kat etmesi gerekir ve bu durum sonsuza kadar sürer. Dolayısıyla hareket ve uzamın varlığı imkânsız hale gelir. ${ }^{2}$

Boşluk fikrinin Antik düşüncedeki en önemli savunucuları atomculuk doktrinini benimseyen Leukippos (MÖ V. yüzyıl) ve Demokritos (MÖ 460-370) olmuştur. Onlar, hareketin inkârının mümkün olmadığını düşünmüş, evrenin ise sonsuz sayıdaki bölünemeyen atomlardan ve boşluklardan meydana geldiğini savunmuşlardır. Onlara göre atomlar bölünemez olduklarından içlerinde boşluk ve devinim söz konusu değildir, ancak birleşip nesneleri meydana getirdiklerinde aralarında boşluklar bulunur. Yani varlıklar bir çeşit varlık (atom) ve yokluk (boşluk) karışımıdır. Buradaki boşluk en az var olan kadar gerçektir. Zira evrende sürekli bir devinim ve değişim olduğu gözlemlenmektedir. Varlığın içinde devinim imkânsız olduğuna göre varlığın içinde devindiği bir boşluk olmalıdır. ${ }^{3}$ Ancak atomcu öğreti

1 Aristoteles, Fizik, çev. Saffet Babür (İstanbul: Yapı Kredi Yayınları, 2005), 213b 10-15, 20-28.

2 Frank Thilly, Felsefenin Öyküsü, çev. İbrahim Şener, I (İstanbul: İzdüşüm Yayınları, 2000), 60; Arda Denkel, İlkçağ’da Doğa Felsefeleri, 2. baskı (Doruk Yayınları, 2011), 47-8.

3 Mary Hesse, "Vacuum and Void", The Encyclopedia of Philosophy, ed. Paul Edwards (New York: Macmillan, 1967), 217; Edward Grant, Much Ado About Nothing: Theories of Space and Vacuum from the Middle Ages to the Scientific Revolution (Londra: Cambridge University Press, 1981), 3. 
açısından boşluk sadece hareketin meydana gelmesi için değil, atom kavramının temellendirilebilmesi için de zorunludur. Çünkü varlık, yokluk tarafından kesintiye uğratılmadıkça fert, ayrık ve izole atomların meydana gelmesi ve birbirinden ayırt edilmesi mümkün olamaz. ${ }^{4}$

İslam düşünce geleneğini önemli ölçüde etkileyen filozoflardan Platon (MÖ 428-348), boşluğu nesnelerin oluş ve bozuluşuna imkân sağlayan bir boyut olarak düşünmüştür. Ona göre âlemin içinde boşluk olduğu varsayılan şey havadır ve hava da bir çeşit cisimdir. Nesnelerin hareketi için boşluğa/yokluğa ihtiyaç yoktur. Âlemin dişında ise yokluk anlamında bir boşluk, hava ve başka bir duyulur-görülür cisim bulunmamaktadır. ${ }^{5}$ Benzer şekilde Aristoteles (MÖ 384-322) de hem âlemin ve cisimlerin içinde hem de âlemin dışında yokluk anlamında bir boşluk bulunmadığını savunmuştur. ${ }^{6}$ Ona göre 'boş' denilen şey gerçekte öyle değildir. Suya bir zar atıldığında nasıl ki zarın kütlesi kadar su taşıyorsa, bir zar havaya atıldığında aynı şey hava için de söz konusu olur. Ama bu duyumla algılanamaz. Çünkü hava görülmemekte ve hissedilmemektedir. Bununla birlikte bir şeydir. Çünkü bir doğrunun bölünmesinin sonu olmadığı gibi maddenin de mümkün inceliğinin bir sınırı yoktur. ${ }^{7}$ Yani ona göre boş olduğu düşünülen yerler aslında ince maddelerle doludur. Böylelikle Antik düşüncede yokluk ile eşdeğer kabul edilen boşluğun, Aristoteles felsefesinde uzaysal bir nitelik kazandığı görülmektedir. ${ }^{8}$ Evrende hareketin olması ise, Aristoteles'e göre, boşluğun varlığını gerektirmez. Tam tersine boşluğun var olması hareketi imkânsız kılar. Çünkü boşlukta yön kavramı yoktur, bu nedenle varlıkların doğal hareketi için bir yön ve sebep de söz konusu olmaz. Ayrıca boşlukta hareketin orada veya burada durması için de hiçbir neden yoktur. Bu durumda boşlukta ya durağanlığın olması ya da başka bir nesneden dolayı devinime başlayan şeyin sonsuza kadar hareket etmesi zorunlu olur. Ona göre hareket nesnelerin aynı anda karşılıklı yer değiştirmesiyle gerçekleşmektedir. ${ }^{9}$

Atomculuğun önemli temsilcileri Epikuros (MÖ 341-270) ve Lucretius (MÖ 9555) Aristoteles’in eleştirilerini dikkate alarak boşluk fikrini daha güçlü argümanlarla

4 Alfred Weber, Felsefe Tarihi, çev. H. Vehbi Eralp, 5. baskı (İstanbul: Sosyal Yayınları, 1998), 36; Mehmet Bulgen, Kelâm Atomculuğu ve Modern Kozmoloji (İstanbul: TDV Yayınları, 2015), 282-3.

5 Platon, Timaios, çev. Erol Günel-Lütfi Ay (İstanbul: Cumhuriyet Yayınları, 2001), 33, 95-96; Fahreddin er-Râzî, el-Metâlibü'l-âliye min ilmi'l-ilâhî, V (Beyrut: Dâru'l-kitâbi'l-Arabî, 1987), 113.

6 Aristoteles, Fizik, 217b 20-28; Aristoteles, Gökyüzü Üzerine, çev. Saffet Babür (Ankara: Dost Kitabevi, 1997), 279a 12-14.

$7 \quad$ Aristoteles, Fizik, 216a 27-32.

8 Aristoteles, Metafizik, çev. Ahmet Arslan (İstanbul: Sosyal Yayınları, 1996), 1048b 10-17; Denkel, İlkçă̆’da Doğa Felsefeleri, 119.

$9 \quad$ Aristoteles, Fizik, 214b 5-35, 215a 15-25. 
savunmaya çalışmışlardır. Epikuros'a göre cisimlerde olduğu gibi boşluğun duyularla algılanması mümkün değildir. Ancak akıl, cisimlerin varlığını ve hareketlerini duyusal olarak gözlememize dayanarak bu hareketlerin gerçekleştiği bir boşluğun varlığını zorunlu görmektedir. ${ }^{10}$ Lucretius ise âlemin cisimler ve boşluktan geldiği iddiasını beş farklı argümanla desteklemeye çalışmıştır. ${ }^{11}$ Fizik ve kozmoloji anlayışlarında ana hatlarıyla Aristoteles'i takip eden Stoacılar ise boşluk konusunda senkretik bu tutum sergilemişlerdir. Onlar, Peripatetik öğretiye uygun olarak âlemin içinde boşluk olduğunu reddetmiş, ancak boşluğu "aktüel anlamda olmasa da içinde varlığın mümkün olduğu yer" şeklinde tanımlayarak âlemin ötesinde bir boşluğun olabileceğini kabul etmişlerdir. ${ }^{12}$ Çünkü onlara göre bu tarz bir boşluk kabul edilmedikçe âlemin sinırlandırılması mümkün olmaz. ${ }^{13}$

İslam düşüncesinde boşluk konusundaki en temel ayrışmanın Meşşâî geleneğin temsilcileri olan İslam filozofları ile atomculuk doktrinini İslam inancına uyarlayan kelâmcılar arasında olduğu söylenebilir. Mu'tezile'nin Basra ekolü ve Eş‘arîler atomcu öğretiyi benimsediklerinden dolayı boşluğu kabul etmiş, İslam filozofları ise iki istisna dışında hem dâhilî hem de haricî boşluğu reddetmişlerdir. ${ }^{14} \mathrm{Bu}$ istisnalar Platoncu geleneği benimseyen ve boşluğu beş ezelî ilkeden biri olarak kabul eden Ebû Bekir er-Râzî (ö. 313/925) ile Aristoteles tenkitçisi Ebü'l-Berekât el-Bağdâdî’dir (ö. 547/1152). ${ }^{15}$

Sonuçta, boşluk kavramıyla ilgili tartışmaların sadece boşluğun ispat veya inkârından ibaret olmadığını, bu tartışmaların daha çok genel kozmolojik kabullerle ilgili olduğunu ve bu kozmolojik tasavvurlara bağlı olarak kabul veya reddedildiğini belirtmek gerekir. ${ }^{16}$ Bu durum Antik felsefede, Aristoteles'te ve İslam filozoflarında böyle olduğu gibi, kelâmcılar için de böyledir.

Epikuros'un boşluk anlayışı için bkz. David Sedley, “Two Conceptions of Vacuum”, Phronesis 27/2 (1982): $183 \mathrm{vd}$.

11 Lucretius'un boşluk argümanları için bkz. A. A. Long ve D. N. Sedley, The Hellenistic Philosophers I: Translations of the Principal Sources, with Philosophical Commentary (Londra: Cambridge University Press, 1987), 23-5.

12 Grant, Much Ado About Nothing, 107.

13 Richard Sorabji, Matter, Space and Motion (Londra: Duckworth, 1988), 125.

14 İslam filozoflarının haricî boşluğu reddetmesinde boyutların sonluluğu (tenâh-i eb‘âd) ilkeleri etkili olmuştur. Zira onlara göre ister cisim, ister boyut, isterse de boşluk veya doluluk olsun hiçbir şey sonsuz olamaz. Boşluk da bu tarz bir sonsuzluğu çağrıştırdığı için reddedilmiştir. Bkz. İbn Sînâ, Uyûnü'l-hikme (Beyrut: Dâru'l-Kalem, 1980), 30-3; Fârâbînnin boşluğu reddi için bkz. Ebû Nasr el Fârâbî, Fi’l-Halâ (Ankara: TTK Basımevi, 1985).

15 İlhan Kutluer, Akıl ve İtikad (İstanbul: İz Yayınc1lık, 1998), 206-8; İslam filozoflarının boşlukla ilgili görüşleri için bkz. Ömer Faruk Erdoğan, "Fârâbî ve İbn Sînâ Felsefesinde Boşluk/Halâ Kavramı", İslâmî Araştırmalar 30/1 (2019): 98-111.

16 Kutluer, Akıl ve İtikad, 182. 
Kelâmcıların boşluk tasavvuruyla ilgili, tespit edebildiğimiz kadarıyla ülkemizde yapılmış müstakil bir çalışma bulunmamaktadır. ${ }^{17}$ Bu eksikliği bir nebze olsun gidermek ve bu konuda yapılacak yeni çalışmalara ön ayak olmak adına Basra ve Bağdat ekolleri arasındaki boşluk tartışmalarını ele almanın yararlı olacağı kanaatindeyiz. Fakat bundan önce kelâmcıların boşluk konusundaki genel yaklaşımlarını tespit etmek yararlı olacaktır.

\section{Kelâmda Boşluk Tasavvuru}

Kelâmda boşluk tartışmalarının ilk olarak ne zaman başladığını tespit etmek güçtür. Bu konuda değerlendirme yaparken boşluk fikrinin kategorik olarak kabul veya reddi ile boşluğun lehine ya da aleyhine argüman geliştirilmesi süreçlerini birbirinden ayırmak gerekir. Bu hususta İbn Meymûn (ö. 601/1204) atomculuk ile boşluk fikri arasındaki bağlantıya işaret ederek kelâmcıların atomculuğu benimsedikten sonra hareketi açıklamak için boşluğu kabul etmek durumunda kaldığını belirtmektedir. ${ }^{18}$ Bu durumda kelâmcıların boşluğu kabul etmeleri atomculuk doktrinini benimsemelerinin zorunlu bir sonucu olmakta ve boşluk fikrinin atomculuğu kelâma dâhil eden Ebü'l-Hüzeyl (ö. 235/849-50) ile başlatılması mümkün görünmektedir. Ancak bu yargının atomculuk düşüncesini kabul eden tüm kelâmcıları kapsamadığını belirtmek gerekir. Zira Ka'bî (ö. 319/931) ve onun mensup olduğu Bağdat ekolü atomcu düşüncelere sahip olmalarına karşın boşluğu reddetmişlerdir. Bunun temel nedeni onların tab'tabiat temelli bir kozmoloji anlayışını benimsemiş olmalarıdır. Çünkü atomlar arası boşluğun kabulü, tabiat fikrini merkeze alan kelâmcıların öngördüğü süreklilik düşüncesini desteklemek yerine, süreksiz ve birbirini etkileme gücüne sahip olmayan nesnelerden müteşekkil bir evren tasavvuru ima etmektedir. Bu nedenle onlar hem boşluğu reddetmiş hem de cevher, mekân ve hareket anlayışlarını süreklilik düşüncesine temel oluşturacak şekilde şekillendirmişlerdir. ${ }^{19}$

Boşluğun lehine ve aleyhine delil üretilmesini dikkate alan Dhanani ise, boşluk tartışmalarını Kindî (ö. 256/870) ile başlatmaktadır. ${ }^{20}$ Ona göre kelâmda boşluk

17 Batı'da boşluk konusunda yapılmış en kapsamlı çalışmanın Dhanani'nin doktora tezi olduğu söylenebilir. Bkz. Alnoor Dhanani, The Physical Theory of Kalām (Leiden: E.J. Brill, 1994), 55-90.

18 İbn Meymûn, Delâletü'l-hâirîn (Kahire: Mektebetü's-sekâfeti'd-dîniyye, t.y.), 197.

19 Bkz. Ebû Reşid en-Nîsâbûrî, el-Mesâil fi'l-hilâf beyne'l-Basriyyîn ve'l-Bağdâdiyyîn (Beyrut: Ma'hedü'l-inmâi'l-Arabî, 1979), 17, 61; Şeyh Müfîd, Evâilü'l-makâlât (Beyrut: Dâru'l-Müfîd, 1993), 96-7; Bağdat ekolünün atomcu-tabiatçı görüşleri için bkz. Ahmet Mekin Kandemir, Mu'tezilî Düşüncede Tabiat ve Nedensellik (İstanbul: Endülüs Yayınları, 2019), 113 vd.

20 Kindî, boşluğu "kendisinde bir şeyin yer tutmadığı mekân" şeklinde tanımlayarak mekân ile mütemekkin arasında zorunlu bir ilişki kurmaktadır. Ona göre mekân varsa zorunlu olarak yer tutan, yer tutan varsa zorunlu olarak mekân vardır. Bu nedenle de mutlak bir boşluktan söz etmek imkânsızdır. Bkz. Kindî, "ỉlk Felsefe Üzerine”, Kindî: Felsefî Risâleler, Mahmut Kaya (İstanbul: Klasik Yayınları, 2014), 133; Kindî’nin boşluğu reddi için ayrıca bkz. Mehmet Bulgen, Klasik İslam Düşüncesinde Atomculuk Eleştirileri (İstanbul: İFAV Yayınları, 2017), 153. 
tartışmaları ise IV/X. yüzyıldan itibaren başlamış ve bunda Ebû Bekir er-Râzînin boşluğu ezelî bir ilke kabul etmesi etkili olmuştur. ${ }^{21}$ İbn Haldûn (ö. 808/1406) ise Eş‘arî mezhebinde boşluk fikrini ilk benimseyen kişinin Bâkıllânî (ö. 403/1013) olduğunu belirtmektedir. ${ }^{22}$ Ancak bu tespitler vakıayı yansıtmamaktadır. Zira konuyla ilgili detaylara girilmemiş olmakla birlikte, hem Eş‘arînin (ö. 324/935-36) hem de Ka'bî̀nin Makâlât'larında yer alan bazı pasajlar her iki âlimin de boşluk tartışmalarından ve delillerinden haberdar olduğunu göstermektedir. ${ }^{23}$ Dahası Ka'bînnin âlemin ötesinde boşluk olup olmadığına ilişkin aktardığı iki görüşün sonunda Abbâd'ın bu iki görüşü de reddettiğini aktarması ${ }^{24}$ boşluk tartışmalarının başlangıç tarihine ilişkin önemli bir ipucu vermektedir. Zira Mu'tezile mezhebine mensup iki Abbâd'dan birinin (Muammer b. Abbâd) vefat tarihi 215/830, diğerininki (Abbâd b. Süleyman) 250/864'dir. Bu durumda Ka'bî̀nin kastı hangi Abbâd olursa olsun boşluk tartışmalarının daha erken dönemlerde başladığı anlaşılmaktadır. İbn Fûrek (ö. 406/1015) ise, Eş‘arînin boşluğu kabul ettiğine ilişkin detaylı bilgiler vermektedir. ${ }^{25}$ Öte yandan Basra ekolünden Nîsâbûrî ve İbn Metteveyh'in eserlerinde de Basra ve Bağdat ekolleri arasındaki boşluk tartışmalarında Ebû Hâşim ve Ka'bî̀nin isimleri zikredilmekte ve bazı deliller bizzat onlara ithaf edilmektedir. ${ }^{26}$ Bu durum boşluk konusunun III/IX. yüzyılın başlarından itibaren kelâmcılar arasında tüm boyutlarıyla birlikte tartışıldığını göstermektedir.

Arapçada bir mekânda hiçbir şey bulunmadığında buraya "boş olmak, boş kalmak" anlamında halâ; bu mekânı bir varlık işgal ettiğinde ise "doluluk, dolu olmak" anlaminda melâ denmiştir. ${ }^{27}$ Kelâmcılar da semantik kökenine uygun olarak halâyı, her türlü cisimden arınmış ve kendisinde hiçbir cevherin/nesnenin bulunmadığı itibari bir boyut olarak tanımlamıştır. Onların nezdinde hiçbir cismin işgal etmediği boşluğun hakiki ve haricî bir varlığı da yoktur. ${ }^{28}$ Kelâmcıların bu tanımı, onların

21 Dhanani, The Physical Theory of Kalām, 72; Kelâmcıların boşluktan anladığı şey ile Râzîninki tümüyle farklıdır. Dahası kelâmcılar onun beş ezelî ilke doktrini içinde mutlak mekân anlamındaki boşluk kavramını İslam inançları açısından tehditkâr bulmuşlardır. Kutluer, Akıl ve İtikad, 202-3; Bulgen, Kelâm Atomculuğu, 286.

22 İbn Haldûn, Mukaddime (Dımaşk, 2004), II, 212-3.

23 Bu argümanlar için bkz. Ebü'l-Kâsım el-Belhî el-Ka'bî, Kitâbu'l-Makâlât (İstanbul: KURAMER Yayınları, 2018), 483; Ebü'l-Hasan el-Eş'arî, Makâlâtü'l-İslâmiyyîn ve ihtilâfi'l-musallîn, II (Kahire: Mektebetü’n-nahdiyyeti'l-Misriyye, 1955), 106-8.

24 Ka'bî, Kitâbu'l-Makâlât, 485.

25 Ebû Bekr İbn Fûrek, Mücerredü Makâlâti'ş-Şeyh Ebi'l-Hasan el-Eş‘arî (Beyrut: Dâru'l-Meşrik, 1986), 206, 271-2, 277.

26 İbn Metteveyh, et-Tezkire fí ahkâmi'l-cevâhir ve'l-a'râz (Kahire: Dâru's-Sekâfe, 1975), 119; Nîsâbûrî, elMesâil, 50-1.

27 İbn Manzûr, Lisânü'l-Arab (Kahire: Dâru'l-Meârif, t.y.), “Halâ”, II/1254-5; “Melâ”, VI/4252.

28 Seyyid Şerif Cürcânî, et-Ta'rifât (Beyrut: Mektebetü Lübnan, 1985), "Halâ”, 105; Muhammed Ali et-Tehânevî, Keşşâfü ıstılâhâti’l-fünûn ve’l-ulûm (Beyrut: Mektebetü Lübnan, 1966), II, 756. 
bazı filozoflarda olduğu gibi boşluğu hava gibi fiziksel bir yapı, üç boyutlu cisimlerin yerleşmesine imkân veren bir boyut veya yüzey gibi düşünmediklerini, ${ }^{29}$ bilakis onu mutlak yokluk/'adem ile eşdeğer gördüklerini ortaya koymaktadır. ${ }^{30}$ Râzî (ö. 606/1210) de bunu teyit etmekte ve kelâmcılar için boşluğun salt yokluk (nefy-i sırf) anlamına geldiğini belirtmektedir. ${ }^{31}$ Halânın, hiçbir kevnin/oluşun/yaratmanın olmadığı boş mekân şeklinde tanımlanması ${ }^{32}$ da bu 'adem durumuna işaret etmektedir. Bu durumda boşluk Allah'ın yarattığı bir şey değil, cevherlerin yaratılıp yaratılmamasıyla ilişkili olarak ortaya çıkan bir mefhum olmaktadır. Zira cevherler hiç yaratılmasa boşluğun varlığı da gündeme gelmeyecektir. ${ }^{33}$

$\mathrm{Bu}$ yaklaşım kelâmcıların boşluğu Yunan atomculuğundaki yorumuna uygun bir tarzda ele aldıklarını göstermektedir. Ancak onlar "boşluk/yokluk vardır" gibi mantıksal bir çelişkiye düşmekten kaçınmak için onun "itibarî/vehmî olduğunu belirtmişlerdir. Öte yandan kelâmcılar, boşluk kavramını tanımlarken mekân kavramından ve özellikle cismin bir yerden bir yere hareketi esnasında mekânla kurduğu ilişkiden hareket etmişlerdir. Çünkü yokluk olarak düşünülen, yani var olmayan bir şeyi sadece kendisinden hareketle tanımlamak imkânsızdır. Bu ancak başka var olanlarla mümkün olabilir. Bu durum aynı zamanda onların Antik Yunan düşünürlerinde olduğu gibi hareketin nasıl gerçekleştiğini açılamak için de boşluk kavramindan istifade ettiklerini göstermektedir.

Mekân ise, kelâmcılara göre, hayyiz ile aynı anlama gelmekte olup cisim gibi uzamlı veya cevher-i ferd gibi uzamsız nesnelerin kapladığı itibarî/vehmî bir boyuttur. ${ }^{34}$ Yani onlar bir cisim tarafından işgal edilen yere mekân/hayyiz, burası hiçbir cisim tarafından işgal edilmediğinde ise ona halâ demişlerdir. ${ }^{35}$ Mücerret bir boşluk anlamında mekân ve hayyiz kavramları birbirinin yerine kullanılmakla birlikte mekânın hayyizden daha genel olduğu belirtilmektedir. Buna göre hayyiz kavramı, itibarî boşluk ancak uzamlı bir şey tarafından işgal edildiğinde kullanılabilir. Bundan dolayı kelâmcılar cevher-i ferd için mütehayyiz demiş, fakat mütemekkin dememişlerdir. ${ }^{36}$ Dhanani, bu iki kavram Cürcânî, Şerhu'l-Mevâklf: Mevâkıf Şerhi çev. Ömer Türker, II (İstanbul: YEK Yayınları, 2015), 199. Eş'arî, Makâlât, II, 106.

31 Râzî, el-Metâlibü'l-âliye, II, 113.

32 İbn Fûrek, Mücerred, 272.

33 Bulgen, Kelâm Atomculuğu, 293.

34 Cürcânî, et-Ta'rifât, "Hayyiz", 99; "Mekân”, 244-5; Tehânevî, Keşşâf, "Mekân”, 1634-5.

35 Cürcânî, et-Ta'rifât, "Halâ", 105; Bu tanım Stoacıların boşluk ve mekân tanımlarıyla birebir örtüşmektedir. Bkz. Long ve Sedley, The Hellenistic Philosophers I, 294.

36 Tehânevî, Keş̧̧̂ff, "Hayyiz", 725. 
arasındaki farkı daha da netleştirmekte ve kelâmcıların mekânı boş uzay anlamında; hayyizi ise boş uzayın uzamlı bir şey tarafından işgal edilerek takdir edilmesi (takdîrî mekân) anlamında kullandıklarını belirtmektedir. Bu durumda mütehayyiz şu anda uzayı işgal eden şeye işaret ederken, hayyiz uzamlı bir şey tarafından işgal edilmiş dolu uzayı, mekân ise işgal edilmemiş boş uzayı ifade etmektedir. ${ }^{37}$

Basra ekolü, yukarıdaki genel tanıma uygun olarak mekânı cismin kütlesinin dayandığı şey olarak tanımlamış ve cismin mekâna dayanmasının onu düşmekten alıkoyduğunu belirtmiştir. ${ }^{38}$ Onlar ayrıca mekân kavramına karşılık cihet ve muhâzât terimlerini de kullanmışlardır. ${ }^{39}$ Bağdat ekolüne göre ise mekân bir şeyi tüm yönlerden çevreleyen ve kuşatan şeydir, böylece cevherler ancak bir mekânda hareket edebilir. ${ }^{40}$ Bağdat ekolünün yokluk anlamında boşluğu kabul etmediği dikkate alınırsa, bu durumda onların mekândan kastının cismi saran ve kuşatan hava veya başka cisimler olduğu anlaşılmaktadır. İbn Sînâ’ya göre mekân, kuşatılan cismin dış yüzeyine temas eden kuşatan cismin iç yüzeyidir. Yani ağır bir cismin üzerine yerleştiği en alt yüzeye mekân denir. ${ }^{41}$ Bu tanım Aristoteles'in mekân tanımıyla uyumludur. Zira o da mekânı "saran cismin sarılan cisimle bitiştiği sınır" şeklinde tanımlamıştır. Ona göre bir şeyin mekânı onu kapsayan hareketsiz cismin ilk sınırıdır. Evrendeki her şeyin bir mekânı vardır; ancak evrenin bir mekânı yoktur. ${ }^{42}$ Eş'arî ise, mekânın cisim, cevher ve araz türünden olmadığı, yani onun itibarî bir kavram olduğu fikrini reddetmektedir. Ona göre mekân, cevher ve cisim türünden olmak zorundadır. Çünkü mekân, içinde varlık bulunduran, ona üst yönden temas eden ve dayanan şeydir. Burada üst ve alt gibi kavramların kullanılması ise tamamen dille ilgili bir durumdur. ${ }^{43}$

Buraya kadar aktardıklarımızdan anlaşılacağı üzere Antik Çağ Yunan felsefesinden itibaren iki tür boşluğun tartışma konusu olduğu görülmektedir. İlki kendileri sonlu fakat sayıları sonsuz olan âlemlerin içinde yüzdüğü haricî boşluk (ekstra-kozmik). İkincisi ve daha çok tartışma konusu olan ise âlemin içinde ve cisimleri oluşturan atomların arasında olduğu kabul edilen dâhilî boşluktur (inter-kozmik). ${ }^{44} \mathrm{Bu}$ ayırım aynı zamanda boşluk kavramının tartışıldığı fizik ve

37 Dhanani, The Physical Theory of Kalām, 66.

38 İbn Metteveyh, et-Tezkire, 62; Nîsâbûrî, el-Mesâil, 188.

39 Cihet ve muhâzât terimlerinin mekân anlamında kullanımı için bkz. İbn Metteveyh, et-Tezkire, 62, 88, 113-4. Ayrıca bkz. Dhanani, The Physical Theory of Kalām, 69.

40 Şeyh Müfîd, Evâil, 100.

41 İbn Sînâ, Kitâbu'l-Hudûd, 32.

42 Aristoteles, Fizik, 212a 5; David Ross, Aristoteles (İstanbul: Kabalcı Yayınevi, 2011), $143-4$.

43 İbn Fûrek, Mücerred, 273.

44 Bkz. H. Austryn Wolfson, Kelâm Felsefeleri, çev. Kasım Turhan (İstanbul: Kitabevi Yayınları, 2001), 377; Grant, Much Ado About Nothing, 14. 
metafizik boyutları ifade etmektedir. Bakıldığında boşluk kavramı yoktan yaratma, mekân, zaman, kıdem ve sonsuzluk gibi metafizik boyutlarıyla; cevher, uzam, hareket, yön, devinim ve sonluluk gibi fizikî boyutlarıyla birlikte ele alınmıştır. Kanaatimizce kavramın doğru anlaşılabilmesi bu iki boyutunun birlikte dikkate alınmasıyla mümkün olacaktır.

\subsection{Boşluğun Metafizik Boyutu: Ekstra-Kozmik Boşluk}

Âlemin dişında/ötesinde bir boşluk olup olmadığı problemi kelâm kaynaklarında "âlemin ötesine bakan kimse bir şey görebilir mi" veya "âlemin dişına elini uzatan kimsenin eli hareket eder mi” soruları etrafında tartışılmıştır. Bu sorular ve muhtemel cevaplarının yer aldığı en eski kelâm metinleri Eş'arî ve Ka'bî'nin Makâlât'larıdır. Bu iki kaynakta da sahipleri zikredilmeden konuyla ilgili belli başlı görüşler aktarilmaktadır. ${ }^{45}$

Bağdat ekolüne göre bir kimse âlemin sonuna gitse ve elini uzatsa eli hareket edemeyecektir. Çünkü bir şeyin hareket etmesi ancak mekânla mümkündür. Âlemin dışında ise herhangi bir varlık olmadığı için el hareket edemez. Aynı şekilde âlemin ötesinin/dışının görülmesi de mümkün değildir. Çünkü görme ancak bir şeyin var olması halinde ve ona ışınların temas etmesiyle mümkün olur. Âlemin ötesinde ise mevcut ve malum hiçbir şey yoktur. ${ }^{46}$ Basra ekolü de bir kimsenin dünyanın son sınırına gitmesi ve arkasına dönüp bakması halinde hiçbir şey göremeyeceğini kabul etmektedir. Çünkü âlemin ötesinde boşluk olsa bile, bu yokluk olduğu için görülemez. Ancak onlara göre elin hareketi mümkündür. Bunun nasıl gerçekleşeceği konusunda ise iki farklı açıllama vardır. İlk görüşe göre elin hareketi bir şeyde olmadan, yani yokluk içinde (lâ fi şey') gerçekleşir. İkinci görüş ise elin hareket etmesi durumunda âlemin ötesindeki boşluğun el için bir mekân olacağını savunur. ${ }^{47}$ Eş'arî ise âlemin ötesinde hiçbir şey olmadığını, olmayan şeyin ise görülemeyeceğini kabul etmiş ve âlemin ötesinde bir mekân olmadığını belirtmiştir. ${ }^{48}$ Ancak Eş'arî’nin bu ifadelerini, onun mekânı cisim türünden bir şey olarak kabul ettiğini göz önünde bulundurarak okumak gerekir. Bu durumda onun âlemin ötesinde yokluk anlamında bir boşluğu reddettiğini söylemek güçtür. Mezhebin önemli temsilcilerinden Cüveynînin yaklaşımı da bu çıkarımı teyit etmektedir. O, âlemin ötesine elin uzanamayacağı görüşünü eleştirmekte ve her cevherin kendine özgü bir hayyize ve kevne sahip olduğu 
kabulünden hareketle iki cevherin birbirinden uzaklaşmasını, dolayısıyla elin âlemin ötesine uzanmasını mümkün görmektedir. ${ }^{49}$

Ekstra-kozmik boşluk problemi ilk olarak Pythagorasçı Archytas (MÖ 410-347) tarafından dile getirilmiştir. Onun zihnindeki problem şöyledir:

Âlemin son sınırına gelsem, örneğin sabit yıldızların ucuna, elimi/sopamı buranın ötesine uzatabilir miydim? Uzatamamam saçma olurdu, fakat eğer uzatabilseydim burası ya bir cisim ya da mekân olurdu. Eğer her seferinde sopanın uzatıldığı bir şey varsa, bu açıkça sonsuz bir şey olmalıdır. ${ }^{50}$

Epikurosçular ve Stoacılar ise şöyle bir akıl yürütmede bulunmuşlardır:

Bir kimse âlemin ötesine elini uzatabilirse, bu durumda elin içinde hareket ettiği bir mekân olmalıdır. Eğer elini uzatamazsa bu durumda da âlemin ötesinde elin hareketine engel olan bir cisim olduğu anlaşılır. Böyle olunca her iki durumda da bir sınıra ulaşmak mümkün olmaz. ${ }^{51}$

Görüldüğü üzere ekstra-kozmik boşluk tartışmaları Antik dönemden itibaren, âlemin bir sınırı olup olmadığıyla ilişkili olarak ele alınmıştır. Aristoteles, boşluk ile sonsuz arasındaki bu ilişkiye dikkat çekerek boşluğu kabul etmenin sonsuz bir evren anlayışına yol açacağına işaret etmiştir. Bu nedenle o, âlemin ötesinde zaman, mekân ve boşluk türünden hiçbir şeyin bulunmadığını savunmuştur. ${ }^{52}$ Stoacılar ise âlemin ötesinde maddî hiçbir varlık bulunmadığına göre, boşluğu sınırlandıracak hiçbir şey de olmayacaktır' diyerek boşluk tarafından kuşatılmış sonlu ve sınırlı bir evren ve onu kuşatan sonsuz bir boşluk fikrine ulaşmışlardır..$^{53}$ Benzer şekilde Şehristânî (ö. 548/1153) de âlemin ötesinde bir boşluk kabul edilmediği takdirde onun sonluluğunu ispat etmenin mümkün olamayacağını belirtmektedir. ${ }^{54}$

Ekstra-kozmik boşluk tartışmaları bir yönüyle de âlemin ezelî olup olmadığı konusuyla bağlantılıdır. Zira boşluğun reddi doğrudan doğruya âlemin ezelî ve yaratılmamış olduğunu ima ederken, yaratılmış olduğunun kabulü ise, âlemin yaratılışından önce bir boşluğun kabulünü gerektirmektedir. Aristoteles "hiçbir şeyin yoktan yaratılamayacağını" söyleyerek boşluktan/yokluktan bir şey üretmeyi imkânsız görmüştür. ${ }^{55}$ İslam filozofları da benzer bir ilkeden hareket ederek âlemin zaman içinde ve sonradan yaratıldığını (hudûs) reddetmişlerdir. Bunun yerine öncesinde boşluk, zaman 
ve mekân türünden bir şeyin olmadığı ezelî bir âlem anlayışını benimsemişlerdir. ${ }^{56}$ Kelâmcılar ise âlemin yoktan yaratıldığını ve hâdis olduğunu, dolayısıyla öncesinde bir yokluğun/boşluğun olduğunu savunmuşlardır. ${ }^{57}$

İbn Rüşd, tam tersine, âlemin içinde yaratıldığı bir boşluğun kabulünün onun hudûsunu problemli hale getireceğini savunmaktadır. Ona göre boşluk kabul edildiği takdirde varlığa gelen her şeyden önce bir mekânın olması gerekir. Eğer bu boşluk mekânla eş anlamlı kabul edilirse bu durumda âlem yaratılmadan önce bir boşluğa, bu boşluğun yaratılması için de başka bir boşluğa ihtiyaç duyulacaktır. Eğer mekân cismin sınırları olarak kabul edilirse, bu durumda da âlemin yaratılması ona sınır/ mekân teşkil edecek başka cisimlerin önceden yaratılmasına bağlı olacaktır. ${ }^{58}$ Her iki durum da kısır döngüye yol açar ve hiçbir şeyin yaratılması mümkün olmaz.

Ne var ki İbn Rüşd'ün bu eleştirisi boşluğun ancak bir 'varlık' olarak kabul edilmesi durumunda geçerli olacaktır. Kelâmcılar ise baştan beri halâyı yokluk ve kevnin, yani yaratmanın olmamasıyla; melâyı ise kevn, yani yoktan yaratmayla ilişkilendirmişlerdir. Bu şekilde boşluk mefhumu yoktan yaratmaya, yani yokluktan varlığa ve varlıktan yokluğa geçişe imkân sağlayan ontolojik bir ilke işlevi görmüştür. ${ }^{59}$ Zira boşluğu savunan kelâmcılar ekstra-kozmik boşluğun reddinin âlemin yoktan yaratılmasına imkân vermeyeceğini, dahası varlığın bütünüyle melâ/doluluk olduğu şeklindeki bir anlayışta ilahî yaratma bütünüyle tamamlanmış olacağından, yeni bir yoktan yaratma eyleminin mümkün olmayacağını düşünmüştür. Bu durumda daima yaratma-yok etme fiilleriyle fâil olan bir tanrı anlayışını temellendirmek de imkânsız olacaktır.

Ekstra-kozmik boşluk tartışmalarının bağlantılı olduğu diğer bir konu, içinde yaşadığımız âlemin dışında başka âlemlerin olup olmadığıdır. Cürcânî (ö. 816/1413) bu bağlantıya işaret ederek boşluğu reddeden filozofların içinde yaşadığımız âlemi tek ve en mükemmel âlem olarak kabul ettiğini, ${ }^{60}$ buna karşın kelâmcıların, sonlu bir sayıda olmak kaydıyla -zira sonsuzluk sadece Allah için söz konusu olabilir- bu

56 Filozofların ezelî yaratma anlayışı için bkz. Hüseyin Atay, Farabi ve İbn Sina’ya Göre Yaratma (Ankara: Ankara Üniversitesi Basımevi, 1974), 133 vd.; Ömer Yıldırım, "İslam Düşüncesindeki Yoktan Yaratma ve Kıdem Tartışmaları: Kelâmcılar ve İbn Sînâ Merkezli Bir İnceleme”, KADER Kelam Araştırmaları X/2 (2012): 251-74.

57 Kelâmcıların yoktan yaratma anlayışı için bkz. Cemalettin Erdemci, Kelam Kozmolojisine Giriş (Ankara: Araştırma Yayınları, 2007), 29 vd.

58 Ebü'l-Velîd İbn Rüşd, el-Keşf an menâhici'l-edille (Beyrut: Merkezü Dirâsâti'l-Vahdeti'l-Arabiyye, 1998), 108-9.

59 Bulgen, Kelâm Atomculuğu, 293, 296.

60 Sonsuz evrenler Yunan atomcuları açısından bir problem teşkil etmez. Bkz. Ahmet Arslan, İlkçağ Felsefe Tarihi I: Sokrates Öncesi Yunan Felsefesi (İstanbul: İstanbul Bilgi Üniversitesi Yayınları, 2006), 330; Platon ve Aristoteles ise başka evrenlerin imkânsız olduğunu savunmaktadırlar. Bkz. Grant, Much Ado About Nothing, 105. 
âlemin benzeri başka âlemleri mümkün gördüklerini belirtmektedir. ${ }^{61}$ Bağdâdî ise (ö. 429/1037-38) Fâtiha suresindeki rabbü'l-'âlemîn ifadesinin tefsirinden hareketle müfessirlerin yaşadığımız âleme benzer on sekiz bin âlem olduğuna ilişkin yorumlarını, bunların da cevher ve arazlardan oluştuğunun kabul edilmesi koşuluyla mümkün görmektedir. ${ }^{62}$ Râzî de bu ifadeleri tefsir ederken, çoklu âlemler ile boşluk arasında doğrudan bir bağlantı kurmaktadır. Ona göre âlemin ötesinde sonsuz bir boşluğun olması, Allah Teâlâ'nın içinde yaşadığımız âlemin dışında, ondan daha büyük ve her birinde içinde yaşadığımız âlem gibi arş, kürsü, yer, gökler, güneş ve ayın bulunduğu binlerce başka âlem yaratmaya kâdir olduğunu göstermektedir. ${ }^{63}$

Esasında âlemin dışındaki boşluk konusunda kelâmcılar arasında çok yoğun tartışmalar olmamıştır. Cürcânî bu durumu tespit ederek boşluğu reddedenler gibi kabul edenlerin de âlemin dışındaki boşluğun ölçülebilir bir varlık olmadığı konusunda hemfikir olduklarını belirtmektedir. ${ }^{64}$ Yani bir bakıma âlemin ötesinde boşluk olduğunu kabul edenler de bunu 'adem/yokluk olarak düşündükleri için, âlemin ötesinde boşluk dâhil hiçbir şeyin olmadığını söyleyenlerle aynı olgusal durumu tespit etmiş olmaktadır. Kelâmcılar arasında asıl tartışmalar âlem-içi/inter-kozmik boşluk konusunda yaşanmıştır.

\subsection{Boşluğun Fizik Boyutu: İnter-Kozmik Boşluk}

Âlemin içinde, cisimlerin ve onu oluşturan atomların arasında bir boşluk olup olmadiğı hususu kelâm kaynaklarında "İki cevherin, aralarında üçüncü bir cevher olmadan ayrık olması mümkün müdür?” sorusu etrafında tartışılmıştır. Yani boşluktan kasıt iki cevherin veya cismin birbirine temas etmeden ve aralarında da temas edecekleri hiçbir şey olmadan bulunabilmesidir. Bu soruya verilecek müspet cevap boşluğun kabulü, menfi cevap ise boşluğun reddi anlamına gelmektedir.

Bağdat ekolüne göre âlem cevherlerle doludur ve onda herhangi bir boşluk bulunmamaktadır. Eğer âlemde boşluk olsaydı birleşik (müctemi) ve ayrık (müteferrik) cevher ve cisimler arasında herhangi bir ayırım yapmak mümkün olmazdı. ${ }^{65}$ Basra ekolü ise cevherler arasında boşluk bulunduğunu kabul etmektedir. Bu hususta Nîsâbûrî, Basra ekolünün boşluğun varlığını sadece mümkün görmediğini, aynı zamanda zorunlu gördüğünü söyleyerek, boşluğun ekolün kozmoloji anlayışı açısından önemine 
dikkat çekmektedir. ${ }^{66}$ Zira Yunan atomcuları gibi kelâm atomcuları da boşluk kabul edilmediği takdirde hareketin imkânsız olacağını düşünmüştür.

İbn Fûrek, Eş‘arî’nin iki cevherin aralarında hiçbir şey bulunmadan ayrık bulunabileceğini, başka bir deyişle âlemde cisimden ve cevherden hâli mekânların varlığını kabul ettiğini aktarmaktadır. Çünkü Eş‘arî âlemin bütünüyle dolu olması durumunda hareketin imkânsız olacağını düşünmektedir. ${ }^{67}$ Cüveynî de boşluk konusundaki tartışmalara dâhil olmakta ve hem âlem-içi hem de âlem-dışı boşluk konusundaki görüşleri aktardıktan sonra kendisini boşluk yanlısı olarak konumlandırmaktadır. ${ }^{68}$ Râzî ise boşluğun ontolojik gerçekliği olmayan soyut bir boyut (bu'du'l-mücerred) olarak anlaşılmasını eleştirmekle birlikte boşluğu kabul ettiğini ifade etmektedir. Eserlerinde boşluk lehine ve aleyhine serdedilen delilleri özetledikten sonra daha çok hareket bağlamında boşluğun varlığını ispat etmeye çalışmaktadır. ${ }^{69}$ Mâtürîdîlerin boşluk konusundaki tutumları diğer kelâm ekolleri kadar belirgin değildir. Mâtürîdî (ö. 333/944), Kitâbu't-Tevhîd'inde âlemin bir mekânda olmaksızın var olduğunu belirtmekte, Bekir Topaloğlu da onun bu ifadelerinin boşluğu reddettiği anlamına geldiğini belirtmektedir. ${ }^{70}$ Pezdevî (ö. 482/1089) de âlemin bir mekânda olmadığını teyit etmektedir. Ayrıca bir kimsenin âlemin ötesine elini uzatmasının mümkün olmadığını söyleyerek âlem-dışı boşluğu reddettiği kanaatini uyandırmaktadır. ${ }^{71}$ Nesefî (ö. 508/1115) ise Ebû Bekir er-Râzînnin iddiasına cevap sadedinde halânın, Allah dışındaki her şey gibi, hâdis olduğunu ispata çalışmaktadır. ${ }^{72}$ Ancak buradaki "âlemin bir mekânda olmaksızın yaratıldı̆̆ı” şeklindeki ifadelerin boşluğun reddini gerektirmediğini belirtmek gerekir. Zira boşluğu kabul eden kelâmcılar da benzer ifadeler kullanmış ve bununla cevherlerin bir mekâna ihtiyaç duymaksızın var olabileceğini belirtmek istemişlerdir. Eğer cevherler var olmak için bir mekâna ihtiyaç duymuş olsaydı bu cevherin kendi zatıyla kaim olduğu ilkesini geçersiz kılardı. Öte yandan cevherin varlığı için gereken bu mekânın da bir mekâna ihtiyaç duyması gündeme gelirdi ki, bu devir ve teselsüle neden olurdu. Bundan dolayı kelâmcılar cevherin bir hayyizde

\footnotetext{
66 İbn Metteveyh, et-Tezkire, 116-7.

67 İbn Fûrek, Mücerred, 206, 272.

68 Cüveynî, eş-Şâmil, 508-9.

69 Fahreddin er-Râzî, el-Erbaî̂n fî usûli’d-dîn, (Kahire: Mektebetü'l-Külliyâti'l-Ezheriyye, t.y.), I, 40; II, 32-8; Fahreddin er-Râzî, Muhassalü efkâri'l-mütekaddimîn ve'l-müteahhirîn mine'l-ulemâ ve'l-hükemâ ve'l-mütekellimîn (Kahire: Mektebetü'l-Külliyâti'l-Ezheriyye, t.y.), 134-6.

70 Ebû Mansûr el-Mâtürîdî, Kitâbu't-Tevhîd, çev. Bekir Topaloğlu (Ankara: TDV Yayınları, 2003), 89.

71 Ebü'l-Yüsr el-Pezdevî, Usûlü'd-dîn (Kahire: Mektebetü'l-Ezheriyye, 2011), 30.

72 Ebü'l-Muîn en-Nesefî, Tebsıratü'l-edille fî usûli'd-dîn, I (Ankara: DİB Yayınları, 2004), 104.
} 
yaratıldığını kabul etmiştir. ${ }^{73}$ Aynı durum âlemin yaratılması için bir mekânın gerekliliği savunulduğunda da gündeme gelecektir. Buna rağmen Mâtürîdîlerin boşluk konusundaki tavırlarını net bir şekilde ortaya koymadıkları ve bu hususta diğer kelâm ekolleri gibi derin tartışmalara girmedikleri açıktır. Bu durum onların "âlemin hudûsunu ve inanç esaslarını ispata yaramayan konularda varlığın hakikatine dair bir araştırmaya girmemeyi” bir ilke olarak benimsemelerinden kaynaklanmaktadır. ${ }^{74} \mathrm{Bu}$ nedenle onların boşluk karşıtı veya boşluk yanlısı olarak konumlandırılması kolay değildir.

\section{Basra ve Bağdat Ekollerinin Boşluğa Dair Argümanları}

Bağdat ve Basra ekolleri arasındaki tartışmalarda serdedilen bir kısmı teorik, büyük kısmı ise deneysel olan delillerin tamamı İbn Metteveyh ve Nîsâbûrî tarafından orijinal halleriyle nakledilmiştir. Buradaki teorik/düşünsel ve deneysel ayırımının tarafımızdan yapılmış kaba bir ayrım olduğunu baştan belirtmek isteriz. Zira ileride görüleceği gibi düşünsel olarak kategorize edilen bazı argümanlar gözlem ve tecrübeye dayalı olduğu gibi deneysel başlığı altında tasnif edilen bazı delillerin de aslında deneye dayanmadığı anlaşılmaktadır. Bu delillere bakıldığında ise her iki ekolün de boşluk konusunda, felsefî gelenekte yer alan tartışmalardan ve delillerden haberdar olduğu görülmektedir. Nitekim bunların bazılarını olduğu gibi, bazılarını da geliştirerek ya da değiştirerek kullanmışlardır. Şimdi bu delilleri detaylı bir şekilde aktarmak ve Antik felsefedeki kökenlerine işaret etmek istiyoruz.

\subsection{Düşünsel Argümanlar}

\subsubsection{Hareket Delili}

Gerek Antik düşüncede gerekse de kelâm atomculuğunda hareket, boşluk savunucularının en güçlü argümanı olarak ön plana çıkmaktadır. Zira boşluk kabul edilmeden hareketin izahında çekilen güçlük, Antik felsefeden itibaren birçok filozofu iki olgu arasında bir tercih yapmaya zorlamıştır. Bazı filozoflar boşluğu reddettiği için hareketi de inkâr etmek zorunda kalmış, bazıları da hareketin inkârını mümkün görmediği için boşluğun varlığını onaylamak durumunda kalmıştır. Basra ekolünün de boşluk lehine öne sürdüğü en önemli delillerden biri harekettir.

74 Nesefî, Tebsıra, I, 72. Mâtürîdîlerin bu yaklaşımıyla ilgili bir değerlendirme için bkz. Mehmet Bulgen, “al-Māturīdī and Atomism”, Ulum: Journal of Religious Inquiries II/2 (2019): 238-9. 
Daha önce Yunan atomcuları Epikuros ( MÖ 341-270) ve Lucretius (MÖ 95-55) tarafından da kullanılan ${ }^{75}$ bu delilin önermesi en yalın haliyle "Eğer âlemde cevher ve cisimlerden hâli boşluklar olmasaydı hareket (tasarruf) imkânsız olurdu” şeklinde formüle edilmiştir. ${ }^{76}$ Önermenin doğruluğunu ispat etmek için öne sürülen argümanlar ise genellikle âlemin bütünüyle dolu olduğu varsayımından hareket etmektedir. Buna göre bir nesnenin hareket ettiği mekânın dolu olduğu (hava veya başka bir cisimle) kabul edilirse, bu durumda hareketin gerçekleşmesi için âlemdeki tüm cisimlerin hareket etmesi gerekir. ${ }^{77}$ Çünkü boş (gibi görünen) yerlerde hareket eden cismin oraya yerleşmesini engelleyen bir hava bulunmaktadır. O hava bu mekândan ayrılıp başka bir mekâna geçmedikçe cismin onun yerine hareket etmesi mümkün olmaz. Onun başka bir mekâna geçmesi de o mekândaki havanın/cismin başka bir mekâna geçmesiyle mümkün olur. Bu durum sonsuza kadar böyle sürüp gider ve sonuçta hiçbir hareket mümkün olamaz. ${ }^{78}$

Buna karşın Bağdat ekolü hareketin, cismin yöneldiği mekândaki havayla eş zamanlı olarak yer değiştirmesiyle gerçekleştiğini savunmaktadır. Bunu mümkün kılan şey ise havanın genleşme ve sıkışma özelliğidir. Yani havanın mekânına doğru hareket ettiğimizde, yöneldiğimiz yöndeki hava sıkışırken, boşalttığımız mekâna doğru hava genleşir ve böylece hareket mümkün olur. ${ }^{79}$ Harekete ilişkin bu teorinin kökeni ise Aristoteles'e dayanmaktadır. Ona göre sıvıların girdap hareketinde olduğu gibi cisimler, aralarında bir boşluk meydana gelmeksizin yer değiştirmek suretiyle hareket edebilir. Aynı şekilde cisimler, içlerinde bulunan şeylerin (örneğin sudaki havanın) dışarı atılmasıyla sıkıştırılabilir. ${ }^{80}$

Basra ekolü karşılıklı yer değiştirmenin imkânsız olduğunu göstermek için bazı deliller ortaya koymuştur. Onlara göre cisim havanın mekânına doğru hareket ettiğinde ona hareket yönünde bir itme kuvveti (i'timâd) uygular. Ancak bu kuvvet havayı cismin mekânına doğru değil, tam tersi yönde hareket ettirir. Bu durumda havanın tersi yönde hareket etmesi ve cismin mekânına geçmesi mümkün olmaz. ${ }^{81}$

Bkz. Long ve Sedley, The Hellenistic Philosophers I, 27, 32.

İbn Metteveyh, et-Tezkire, 117; Nîsâbûrî, el-Mesâil, 47.

Platon bu handikaptan kurtulmak için hareket eden nesnenin havanın yerini aldığını, havanın da başka bir mekâna geçtiğini ve bu olayın tüm evrende dairevi bir biçimde hiç durmadan devam ettiğini savunmuştur. Ona göre suların akması, fırlatılan cismin havadaki hareketi, yıldırım düşmesi, nefes alıp vermek, tedavi amaçlı sırta şişe çekmek gibi olayların tümü bu şekilde meydana gelmektedir. Platon, Timaios, 95-6.

İbn Metteveyh, et-Tezkire, 117; Nîsâbûrî, el-Mesâil, 47.

Nîsâbûrî, el-Mesâil, 47.

Aristoteles, Fizik, 214a 5-35; Ross, Aristoteles, 145.

İbn Metteveyh, et-Tezkire, 117; Nîsâbûrî, el-Mesâil, 48. 
Öte yandan hava ters yönde hareket etse bile cismin mekânına geçebilmesi için, cisim oraya geçene kadar burası gerçek anlamda "boş" kalmalı, öncesinde başka bir hava oraya dolmamalıdır. Bu durumda boşluğu inkâr etmek anlamsız olur. Ancak bu durumda bile karşılıklı yer değiştirmeyi temellendirmek mümkün olmaz. Çünkü cismin burayı tamamen boşaltması havanın yerine geçebilmesiyle mümkün olabilir. Hava da ancak başka bir mekâna geçerek kendi mekânını boşaltabilir. Böylece bir kısır döngü ortaya çıkar ve hareket mümkün olmaz. ${ }^{82}$

Basra ekolü bu durumun ortaya çıkardığı mantıksal çelişkiyi izah etmek için günlük hayattan bazı örnekler verir. Buna göre eşzamanlı karşılıklı yer değiştirme mümkün olsaydı, içi suyla dolu iki testiden birini ötekine boşalttığımızda aynı anda birindeki suyun diğerine dolması gerekirdi. Benzer şekilde tek seferde sadece bir kişinin geçebileceği dar bir geçitte karşılaşan iki kişinin aynı anda birbirlerinin yerine geçmek suretiyle yer değiştirebilmesi de mümkün olurdu. ${ }^{83}$ Basra ekolü açısından bu örneklerdeki temel problem iki arazın aynı anda tek bir mekânda bulunmasını gerektirmesidir. Zira onların düşünce yapısında hareket de bir oluş (kevn) arazıdır ve aynı mekânda eş zamanlı iki hareketin meydana gelmesi mümkün değildir. Aksi halde iki arazın tedâhülü söz konusu olacaktır. Ancak Bağdat ekolünün verdiği örnekte bir cismin havadaki hareketi tasvir edilmektedir. Basra ekolünün cevap mahiyetinde verdiği örneklerde ise iki sıvının ve iki katının yer değiştirmesi ele alınmıştır. Yani Basra ekolünün genleşme ve büzülme konusunda katı, sıvı ve gaz arasında bir ayırım yapmadığı anlaşılmaktadır. Çünkü onlara göre boşluğu reddedenler cisimlerin aralarında hiçbir boşluk kalmayacak şekilde birleştiğini savunmaktadır. Bundan dolayı diğer cisimler gibi havanın da genleşmesi ve sıkıştırılmasından söz edilemez. Ayrıca hava sıkıştırılsa bile, sıkışan hava hareket için bir boşluk meydana getirmeyecektir. Çünkü boşluk reddedildiği için havanın boşalttığı yerler her durumda başka cisimlerle dolu olacaktır.

\subsection{2 Ölçme ve İdrak Delili}

Bağdat ekolünün boşluğu reddetmek için öne sürdüğü en güçlü argüman ölçme ve boyut problemine dayanan delildir. Bu delile göre eğer iki cevher arasında boşluk olsaydı, bu boşluğun başka iki cevher arasındaki boşluktan daha az, daha çok veya ona eşit olduğu söylenemezdi. Çünkü ölçülebilen şeyler gerçek bir varlığa sahip olan cisim veya ve cevher türünden olmalıdır. Boşluk ise hakiki bir varlığa sahip olmadığı 
için ölçülmesi imkânsızdır. Bu nedenle iki cevher arasındaki boşluğun herhangi bir ölçü birimine konu olması mümkün değildir. ${ }^{84}$ Ancak tecrübeyle sabit olduğu üzere cisimler ve cevherler arasındaki boşluk ölçülebilmektedir.

Bu delilin Antik felsefedeki kökenine Parmenides'in akıl yürütmesinde rastlamak mümkündür. Ona göre cisimlerin arasında olduğu öne sürülen boşluk veya aralık ya bir varlıktır ya da değildir. Eğer bu boşluk bir varlıksa, o zaman varlıkla doludur ve dolayısıyla varolan sürekli demektir. Öte yandan boşluk bir varlık değilse, o var olmayandır. Gerçekte var olamayan olanaksız olduğundan, böyle bir boşluk da olamaz. Dolayısıyla varolan süreklidir ve bundan dolayı da birdir. ${ }^{85}$

Basra ekolü iki cevher arasındaki mesafeyi ölçmek için aralarında ölçüme konu olacak bir cismin veya cevherin olmasını zorunlu görmez, onlara göre takdirî olarak burada bir cevherin olduğu düşünülür ve aradaki mesafeye ilişkin bir tahminde bulunulabilir. Böylece iki cevher arasındaki boşluğun başka iki cevherden daha büyük veya daha küçük olduğu söylenebilir ve belli ölçülerde bir cismin olması durumunda burayı işgal edeceği ön görülebilir. ${ }^{86}$ Sözgelimi Allah'ın bir cisim yarattığını ve hemen ardından hiç ara vermeksizin başka bir cisim yarattığını ve yine aralıksız üçüncü bir cisim yarattığını düşünelim. Birinci ile ikincinin arasında hiçbir şey olmasa bile kıyas yoluyla birinci ile üçüncünün arasındaki sürenin birinci ile ikinci arasındaki süreden daha fazla olduğu söylenebilir. Ancak eğer birinci ile ikincinin yaratılması arasında bir zaman geçmiş olsaydı zaten bu süre ölçülür ve üçüncünün yaratılması arasındaki fark tespit edilirdi. ${ }^{87}$

Bağdat ekolü bu itirazlara yanıt verirken, ayrık iki cevher arasında var olduğu iddia edilen boşluğun takdiri olarak ölçülebilmesi için önce idrak edilmesi, bunun için de görülebilir olması gerektiğini ileri sürer. Ancak onlara göre sadece var olan şeyler görülebilir, boşluk ise var olmadığı için görülemez. Bu durumda aradaki boşluğa varsayım olarak bile üçüncü bir cismin gireceği düşünülemez. Ancak bu cevherler ayrık bir şekilde algılanabildiğine göre bu durumda aralarındaki boşluğun yokluk değil, varlık ve doluluk olması gerekir. ${ }^{88}$

Boşluğun yokluk olarak kabul edilmesini hedef alan bu eleştirilerin benzerleri sonraki dönem kelâmcıları ve İslam filozofları tarafından da dile getirilmiştir. Buna göre boşluk, yokluk olarak kabul edildiği takdirde iki şey arasında bulunduğunda 
daha az veya daha çok olması mümkün olmaz. Ancak yeryüzü ile gökyüzü arasındaki mesafe iki şehir arasındaki mesafeden daha çoktur. Ayrıca bu iki mesafenin ölçüsü bellidir. Dolayısıyla aralarında oransal bir ilişki kurulabileceği gibi bu mesafelerin yarısı, üçte biri veya dörtte birinden de söz etmek mümkündür. Açıktır ki bu tür nitelemeler kesinlikle "bir şey olmayan" üzerine yüklenemez. ${ }^{89}$

Basra ekolü ise, iki cevherin ayrık bir şekilde bulunduğu ispat edildiğinde, bir cevherin bir yönde, diğerinin başka bir yönde ve belli bir uzaklıkta bulunduğunu idrak etmek için aralarındaki boşluğun görülmesinin gerekmediğini savunmaktadır. ${ }^{90}$ Ancak bu cevap boşluğun algılanamaz olduğu iddiasına bir yanıt niteliği taşımamaktadır. Basralıların iki cevher ayrı ayrı algılandıktan sonra aralarındaki boşluk görsel olarak algılanmadan, bir cevherin diğerine belli bir uzaklıkta olduğu sonucuna nasıl ulaştıkları da açık değildir. ${ }^{11}$ Sonuçta, Basra ekolünün, boşluğun hakiki bir varlığa sahip olmamasının ortaya çıkardığı ölçme problemini, var olmayan bir şeyin nasıl olup da algıya konu olabildiğini ikna edici bir biçimde açıklayamadığı söylenebilir.

\subsubsection{Düşünce Deneyleri}

Basra ekolü cisimlerin fenâ ve bekâsından hareketle iki farklı düşünce deneyi üretmiştir. Buna göre boşluk karşıtı Bağdat ekolü, cisimlerin kendilerine ilişen bir bekâyla süreklilik kazandığını ve cisimlerin bekâsının sadece bu arazın varlığına bağlı olduğunu kabul etmektedir. Buradan hareketle Basra ekolü şöyle bir varsayımda bulunur: Allah Teâlâ'nın tek bir cevheri ve sadece bunda bekâyı yaratması mümkün olduğu gibi yarattığı varlıklardan bir kısmı için bekâ yaratmayıp onları yok etmesi, bazılarını ise sürekli kılması mümkündür. Örneğin Allah yer ve gök için bekâ yaratıp ikisi arasında bulunan hiçbir varlık için bekâ yaratmayabilir. Eğer Bağdat ekolü bunu mümkün görürse bu durumda onlara, Allah yer ile gök arasındaki tüm varlıkları yok etse ve geriye sadece yer ve gök kalsa ne olur, birbirlerine doğru hareket edip birleşirler mi, yoksa ayrı durmaya devam mı ederler sorusu yöneltilir. Eğer yerin ve göğün ayrı kalabileceğini kabul ederlerse bu durumda ikisinin arasındaki boşluğu kabul etmiş olurlar. Yok, eğer birleşeceklerini söylerlerse bu durumda, yokluğun kat

90 İbn Metteveyh, et-Tezkire, 120; Nîsâbûrî, el-Mesâil, 52; Kelâmda hareket, sükûn, ictimâ‘ ve iftirâk gibi oluşların görmeye konu olup olamayacağıyla ilgili tartışmalar için bkz. Hasan Cansız, "Rü’yetullah Meselesi Çerçevesinde Kelam-Bilim İlişkisi” (Doktora tezi, Necmettin Erbakan Üniversitesi, 2019), 243 vd. 
edilmesi mümkün olmadığından tafrayı, yani sıçrama yoluyla hareketi kabul etmek durumunda kalırlar. ${ }^{92}$

İkinci deney daha basit bir örnekten hareket etmektedir. Buna göre $\overleftrightarrow{\mathrm{ABCDEF}}$ şeklinde altı cüzden oluşan düz bir çizgi var sayılır. Bu çizginin ortasındaki dört cüz $\overrightarrow{\mathrm{BCDE}}$ bir anda kaldırıldığında, uçta kalan iki cüz $\stackrel{\leftarrow}{\mathrm{A}}$ ve $\overrightarrow{\mathrm{F}}$ birleşmek için birbirlerine doğru hareket ederler ve tam ortada, yani $\bar{C}$ ve $\bar{D}$ atomlarının başlangıçta bulunduğu yerde birleşirler. Ancak bu iki cüz birleşmek için hızla hareket ederse yolları üzerinde bulunan $\overline{\mathrm{B}}$ ve $\overline{\mathrm{E}}$ cüzlerinin mekânına uğramadan tafra/sıçrama yoluyla hareket etmeleri gerekir ki bu mümkün değildir. Ya da oldukları yerde, bir müddet de olsa aralarında başka bir cevher olmaksızın ayrı kalırlar. Bu da boşluğun varlığını ispat eder. ${ }^{93}$

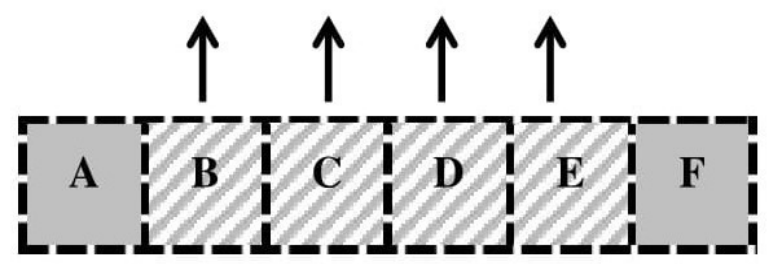

Şekil 1: Düșünce Deneyi

Bu örneklerde Basra ekolü, boşluk kabul edilmediği takdirde hareketin ancak tafrayla mümkün olabileceğini, aksi halde hareketin imkânsız olduğunu ortaya koymak suretiyle boşluk karşıtlarını ilzam etmeye çalışmaktadır. Bağdat ekolünün bu örneklere nasıl cevap verdiği açık değildir, fakat onların genel kabullerinden hareketle ya ortadaki dört cüz kaldırıldığında bunların yerini havanın alacağı ve kenarlardaki cüzlerin birleşmeden kalacağı ya da ortadaki cüzler kaldırıldığında, kenardaki cüzlerin bunların yerini alan havayı kat etmek suretiyle birleşebileceği söylenebilir. ${ }^{94}$

\subsection{Deneysel Argümanlar}

Daha ziyade Bağdat ekolü tarafından kullanılan boşluk karşıtı deneysel argümanlar büyük oranda, "doğa boşluktan nefret eder (nature abhors a vacuum)" ilkesine dayanmaktadır. İlkenin kökeni tam olarak bilinmemekle birlikte, ${ }^{95}$ bu konuda ilk deney 
yapanlardan birinin Bizanslı Philon (MÖ 220-280) olduğu kabul edilmektedir. Üstelik teorinin erken dönemini oluşturmasına karşın onun bazı deneyleri kelâmcıların kullandıklarından daha karmaşık bir düzenek içermektedir. ${ }^{96}$

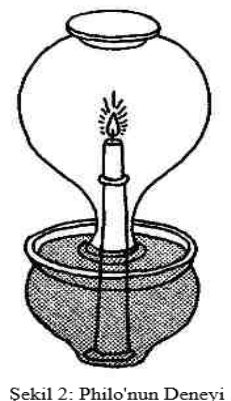

Philon'un deneyi: Bu deneyde ağzı geniş ve içi su dolu bir kaba, yarısı dışarıda kalacak şekilde yanan bir mum batırılır. Daha sonra küçük bir ağzı ve dar bir boynu olan cam fanus, suya temas edecek şekilde ters çevrilerek mumun üzerine kapatılır. Böylece yanan mumun dışarıdan havayla teması kesilir. Bu şekilde bir süre yandıktan sonra, kabın içindeki suyun fanusun dar boynundan yukarı doğru yükseldiği görülür. Philo'ya göre bunun nedeni yanan mumun fanusun içindeki havayı tüketmesidir. Tükenen havanın yerine boşluk oluşmaması için, su yükselerek havanın yerini almıştır. ${ }^{97}$

Konuyla ilgili deney yapanlardan biri de kesintisiz boşluğu (continuous vacuum) reddetmekle birlikte cisimlerin içine yayılmış süreksiz ve çok küçük boşlukların varlığını kabul eden İskenderiyeli Heron'dur (MS 10-70)..$^{98} \mathrm{O}$, bu düşünceye ulaşırken pompa ve sifonlardan oluşan bazı cihazların işleyişinden ve doğanın boşluktan nefret ettiği ilkesinden hareket etmiştir. Ona göre bu cihazlar çalışma esnasında büyük boşlukların oluşmasını engellemek için cisimlere bir çekim kuvveti uygulamaktadır. ${ }^{99}$ Philon ve Heron'un bu görüşleri, İslam dünyasındaki boşluk tartışmalarının hareket noktalarından birini teşkil etmiştir. Kelâmcıların istifade ettiği diğer bir kaynak ise Simplikios (MS 490-560) ve Philoponos (MS 490-570)100 gibi Aristoteles şârihleridir. Onların Arapçaya tercüme edilmiş şerhlerinde boşluğun kabul veya reddine ilişkin tartışmalar kelâmcılar üzerinde etkili olmuştur. ${ }^{101} \mathrm{Bu}$ bağlantılara, yeri geldiğinde örnekler vererek işaret etmeye çalışacağız.

\subsection{1 Şişe Deneyleri}

Şişe deneyleri, havası alınmış dar ağızlı bir şişenin suya batırılmasıyla yapılmaktadır. Nîsâbûrînin belirttiğine göre bu delili ilk olarak Basra ekolü ortaya koymuş, daha sonra da Ka'bî bunu kendi görüşlerini savunmak için kullanmıştır. Ancak şişe deneylerinin tarihi Empedokles'e (MÖ 495-435) kadar uzanmaktadır. O, havanın bir cisim olduğunu ispat sadedinde şöyle bir örnek vermiştir: Bir şişenin ağzını parmağımızla 
kapattıktan sonra ters çevirip suya daldırsak ve daha sonra parmağımızı çeksek şişeye su dolmayacaktır. Fakat şişeyi düz bir şekilde suya daldırdığımızda su şişeye dolacaktır. Empedokles bundan, şişede bulunan havanın bir cisim olduğu ve ilk örnekte suyun şişeye dolmasına engel olduğu çıkarımını yapmaktadır. ${ }^{102}$ Aristoteles'in Gökyüzü Üzerine adlı eserinde de yerin durağan olup olmadığı konusu tartışılırken bu örneğe atıfta bulunulmaktadır. ${ }^{103}$

Basra ekolü ise benzer bir düşünceden hareketle boşluğu ispat etmeye çalışmıştır. Onların geliştirdiği delile göre, havası emilip ağzı parmakla kapatılan bir şişe ters çevirip suya daldırılırsa ve sonra şişenin ağzı açılırsa şişeye su dolar. Eğer şişedeki hava boşaltılmasaydı suyun şişeye girmesi mümkün olmazdı. Bu nedenle şişedeki havanın boşaltılması onda boşluk meydana getirmiş ve böylece suyun şişeye girmesi mümkün olmuştur. Delilin farklı bir versiyonu Ebû Hâşim'in talebelerinden Ebû İshâk b. Ayyâş'a (ö. 360/970) atfedilmektedir. Kabarcık delili olarak adlandırabileceğimiz bu delile göre, havası emilip ağzı parmakla kapatılan bir şişenin suya daldırıldıktan sonra ağzı açılırsa suyun şişeye girdiği ancak hiç kabarcık sesi çıkarmadığı görülür. Eğer şişede hava kalmış olsaydı içine su girdiği esnada kabarcık sesi duyulurdu. Böylece emildikten sonra havanın şişeden çıktığı ve yerine bir boşluk oluştuğu anlaşılır ki bu sayede su şişeye dolar. Nîsâbûrî̀ye göre bu delil boşluğun varlığını ispat eden en güçlü delildir. ${ }^{104}$

Ka'bî ise bu delili boşluğu reddetmek için kullanmıştır. Ona göre havası alınan bir şişe, ağzı kapalı bir halde ters çevrilip suya batırılırsa ve daha sonra ağzı açılırsa, normalde aşağı yönde hareket etmesi gereken suyun yukarı doğru hareket ederek şişeye dolduğu görülür. Ona göre bunun nedeni âlemde boşluğun bulunmamasıdır. Zira şişenin havası emilirken şişe tam olarak boşalmamış; içindeki soğuk hava dışarı çıkarılırken bu esnada nefesle birlikte sıcak hava içeri girmiştir. Sıcak olanın özelliği ise bir şeyin hareketini hafifletmesi ve hızlandırmasıdır. Bu nedenle şişe suya daldırıldığında içindeki sıcak hava suyu hızlıca şişeye çeker. Bu da suyun tabiatının aksine yukarı doğru hareket etmesini ve şişeyi doldurmasını açıklar. ${ }^{105}$

105 İbn Metteveyh, et-Tezkire, 120-21; Nîsâbûrî, el-Mesâil, 49; Îcî, boşluk karşıtlarına bir şişe deneyi daha atfetmektedir. Bu deneyde, baş tarafı kapalı bir boru, bir kısmı dışarıda kalacak şekilde bir şişeye yerleştirilir ve içine hava girip çıkmayacak şekilde ağzı sıkıca kapatılır. Şişenin boynu ile boru arasındaki boşluklar da iyice kapatılır. Daha sonra boru şişeye doğru sokulduğunda, şişenin dışa doğru kırıldığı; boru şişenin dişına doğru çekildiğinde ise bu kez şişenin içe doğru kırıldığı görülür. Boşluk karşıtlarına göre eğer şişe başka hiçbir şey almayacak şekilde havayla ve içindeki boruyla dolu olmasaydı şişe kırılmazdı. Bu hem tedâhülün hem de boşluğun imkânsız olduğunu göstermektedir. Bkz. Adudüddin el-Î̃̂î, el-Mevâkıffî ilmi'l-kelâm (Beyrut: Alemü'l-Kütüb, t.y.); Cürcânî, Şerhu'l-Mevâkıf, II, 197-9. 
Ebû Hâşim bu argümanın hacamat aleti deliliyle ${ }^{106}$ çelişkili olduğunu düşünür. Çünkü Ka'bî̀ye göre hacamat şişesinin havası emilip boyundaki iki damar üzerine konulduğunda et şişenin içine doğru çekilir, zira et şişeden boşaltılan havanın yerine geçer. Ebû Hâşim’e göre eğer Ka'bînnin dediği emme işleminde şişedeki soğuk hava nefesteki sıcak havayla yer değiştirmiş olsaydı, etin şişeye doğru çekilmesi mümkün olmazdı. Dahası şişenin içine sıcak hava girmesi ancak şişeye üfürmekle olur, emme işlemi ise şişeyi boşaltır. Ka‘bî’nin savunduğu şeye göre emme ve üfürme işleminin aynı sonucu doğurması gerekir. Bu ise açıkça yanlıştır. Ebû Hâşim bu çelişkili duruma şöyle bir örnek verir:

Hacamat şişesini, içindeki havayı ateşle 1sıttıktan sonra ters çevirip suya daldırdığımızda su şişeye girmeyecektir. Bu da Ka'bî’nin tezini çürütmektedir. Çünkü şişeye suyun girmesinin nedeni içindeki sıcak hava değil, boşluktur. Eğer Ka'bînnin dediği doğru olsaydı bu örnekte de suyun şişeye girmesi gerekirdi. ${ }^{107}$

Ancak Ebû Hâşim’in verdiği bu örnek tecrübe edildiğinde, onun hatalı olduğu anlaşılmaktadır. Zira içindeki hava 1sıtılsa bile su yine şişeye girecektir. Bu durum Basra ekolünün bazı delillerinin tecrübeye dayanmadığını göstermektedir. ${ }^{108}$

İbn Metteveyh de havanın boşaltılması esnasında, şişeye sıcak nefesin girmesini mümkün görmez. Ona göre emme eylemi şişeden havayı dışarı çıkarır, içeri sokmaz. Şişeye hava girmesi için ise üfürmek gerekir. Eğer şişede hava kalmış olsaydı, daha önce zikredilen örnekte olduğu gibi, su içeri girdiği esnada uyguladığı basınç kabarcık sesinin çıkmasına sebep olurdu. Bununla birlikte İbn Metteveyh havası alınıp ısıtılan bir şişe ters çevrilip suya batırıldığında suyun içine dolacağını kabul etmektedir. Ona göre bunun nedeni şişe ters çevrildiğinde şişenin alt kısmında kalan sıcak cüzlerin, yukarı doğru hareket etmesi ve bu nedenle suyu şişeye doğru çekmesidir. Benzer bir şekilde üzerine güneş vuran topraktaki buhar da göğe doğru yükselmektedir. Ancak ateşle 1sıtılsa bile içindeki hava boşaltılmadıkça şişeye su girmeyecektir. ${ }^{109}$

Mu'tezilî âlimler arasındaki şişe tartışmaları Ka'bî ve Ebû Hâşim ile çağdaş olan Fârâbînnin (ö. 339/950) de ilgisini çekmiş ve bu konuda müstakil bir risale telif etmesine neden olmuştur. Risalenin başında Basra ekolünün şişe deneylerini aynı şekilde zikretmesi ve risalenin onlara cevap sadedinde devam etmesi, ${ }^{110}$ risalenin telif sebebinin ekolün bu deneylerden hareketle boşluğu savunmaları olduğunu 
göstermektedir. Fârâbî risalesinde, şişe deneylerinde gözlemlenen olguların gerçek olduğunu, ancak bu olgulardan hareketle boşluk fikrine ulaşılmasının yanlış olduğunu savunmaktadır. Ona göre bu deneylerde şişedeki hava tamamıyla emilmemekte ve şişe tamamıyla boşalmamaktadır. Aksine emmeyle boşalan hava şişedekinin üçte biridir. Geriye kalan hava, yapısı itibariyle kendisini kuşatan cisimlerin şeklini aldığından, genişleyerek şişeyi tekrar doldurur. Ancak havanın bu tabi hareketine izin verilmeden şişe suya daldırıldığında, hava ile su mekân değiştirme özelliğine sahip olduklarından, boşalan havanın yeri suyla dolacaktır. ${ }^{111}$

\subsubsection{Hacamat Aleti Deneyi}

Bağdat ekolünün formüle ettiği bu delil, şişe deneylerinde olduğu gibi boşalan bir mekânı başka cisimlerin hızla doldurduğunu ve böylelikle doğada boşluğun imkânsız olduğunu göstermeye yöneliktir. Bu deneye göre hacamat yapan kimseler hacamat bardağını boyundaki iki damarın üzerine koyup içindeki havayı boşalttıklarında et şişenin içine doğru şişer. Bunun nedeni ise âlemde boşluğun imkânsız olmasıdır. ${ }^{112}$ Bu delil özü itibariyle şişe deneyleriyle aynı fikre dayanmaktadır. Aradaki tek fark dar ağızlı şişenin yerini hacamat bardağının, suyun yerini etin almış olmasıdır.

Basra ekolüne göre etin şişeye çekilmesinin nedeni, şişedeki havanın etin cüzleri arasına karışmasıdır. Zira şişedeki havanın emilmesi, etin cüzlerine yapışık halde bulunan havanın şişeye çekilmesine ve beraberinde etin de çekilmesine sebep olur. Basra ekolüne göre bu olayın bir benzeri suya batırılan bir borudaki hava emildiğinde gerçekleşir. Suyun cüzlerine karışmış hava beraberinde suyu da şişeye doğru çekecektir. Bunun delili ise hacamat işleminin bir taşın üzerinde yapılması durumunda taşın şişeye doğru şişmemesidir. Çünkü taş sert ve sıkı bir yapıya sahip olduğundan hava onun cüzleri arasına girememiştir. Şişedeki havayla yer değiştirecek bir hava olmayınca da taşta bir çekilme meydana gelmez. Etin hacamat bardağının içine çekilmesinin ve suyun şişenin içine girmesinin nedeni, bu ikisinin atomları arasına havanın karışmış olmasıdır. Eğer Bağdat ekolünün iddiası doğru olsaydı, et ve su ile taş arasında bir fark olmaması gerekirdi. ${ }^{113}$

Borudaki havanın çekilmesiyle birlikte suyun da yukarı doğru çekileceği olgusuna ilk olarak Aristoteles işaret etmiş ve "suyun yukarı çekilmesi yüzeyinin havayla bir

111 Fârâbî, Fi’l-Halâ, 4-5, 14-5 Fârâbî, Bağdat ekolüne benzer bir şekilde, havası alınan şişede hala bir boyut, mesafe ve hacim olduğundan hareketle boşluğu reddetmektedir. Bkz. Fârâbî, Fi’l-Halâ, 5-6, 9-10.

112 İbn Metteveyh, et-Tezkire, 121; Nîsâbûrî, el-Mesâil, 52.

113 İbn Metteveyh, et-Tezkire, 121; Nîsâbûrî, el-Mesâil, 52-3. 
araya getirilmesi ve yukarıdan emmek suretiyle bir kuvvet uygulanmasıyla mümkün olur"114 demiştir. Ancak yukarıdaki örneğin neredeyse aynısı ilk olarak Bizanslı Philon tarafından zikredilmiştir. Ona göre şarabı test etmek için kullanılan kamış, bir ucundan şaraba batırılıp öteki ucundan havası emilirse, yüzeyine yapışan havadan dolayı, emmeyle birlikte şarabı da kamıştan yukarı doğru çıkaracaktır. Havanın bu şekilde suyu çekme gücü Simplikios ve Philoponos tarafından da Aristoteles'in ilgili pasajları üzerine yaptıkları yorumlarda vurgulanmıştır. ${ }^{115}$ Îcînin de bu örneği filozoflara atfen zikretmesi, örneğin Antik düşüncedeki kökenlerinin farkında olduğunu göstermektedir. ${ }^{116}$

Nîsâbûrî, bu hususta zekice tasarlanmış bir deney daha önermektedir. Bu deneyde düz bir kâğıdın her iki tarafına hacamat bardağı yerleştirilir ve her ikisinin de havası alınır. Bu durumda iki hacamat bardağı arasında kalan kâğıt için üç ihtimal söz konusu olur. Kâğıt ya olduğu gibi kalır ya da bardaklardan birinin içine doğru çekilir. İki bardağa birden çekilmesi mümkün değildir. Bu durumda olası üç ihtimalde de bardaklarda bir boşluk meydana gelecektir. Bu da âlemde boşluk olduğunu göstermektedir. ${ }^{117}$

\subsubsection{Kırık-Çıkıkçı Deneyi}

Bağdat ekolünün boşluk aleyhine gündeme getirdiği bu delil kırık-çıkıkçıların uyguladığı tedavi yönteminden hareketle tasarlanmıştır. Ancak bu da şişe ve hacamat deneylerinde olduğu gibi doğanın boşluk oluşmasına engel olacağı var sayımına dayanmaktadır. Delile göre, kırık-çıkıkçı, kırılan kemiği tekrar yerine yerleştirmek için kemiğin üzerine bir miktar hamur ('acîn), sonra hamurun üzerine bir parça kömür koyar ve kömürün de üzerini bir fincanla kapatır. Daha sonra kömürün 1sıttı̆̆ fincandaki hava fincanın kenarlarındaki boşluklardan dışarı çıkar. Havanın çıkmasıyla sırasıyla kömürün ateşi havanın yerine; hamur ateşin yerine; kırık olan kemik ise hamurun yerine yükselerek geçer. Böylece kırık kemik kendi yerine yerleşmiş olur. Tüm bunların nedeni ise âlemde boşluğun imkânsız olmasıdır. ${ }^{118}$ 

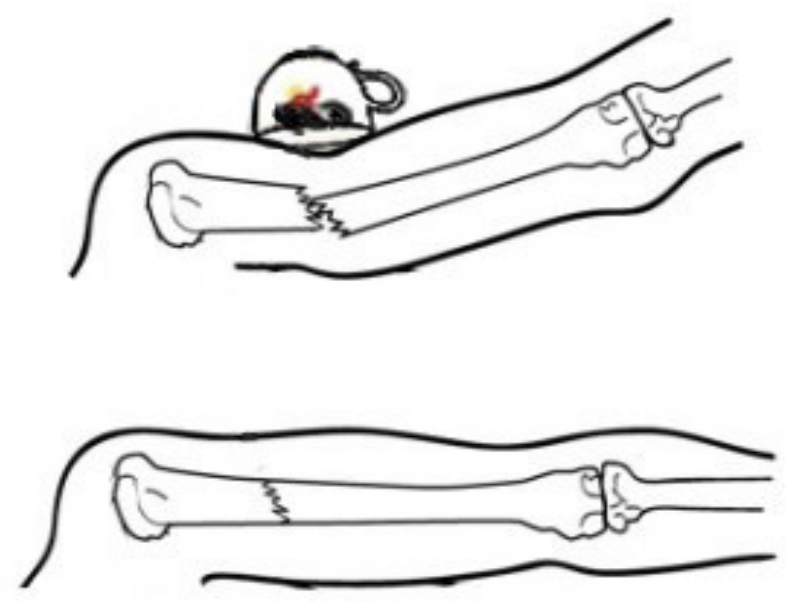

Şekil 3: Kırılan kemiğin yerine yerleştirilmesi

Basra ekolü bu olayı ateşin ítimâdından ${ }^{119}$ hareketle açıklamaktadır. Onlara göre kömür hamurun üzerine konduğunda ve üzerine fincan kapatıldığında, ateşin normal hareket yönü (yukarı) engellenmiş olur. O da zorunlu olarak aşağı doğru bir i'timâd (süflî müctelib i'timâd) meydana getirir. Böylelikle kömürdeki ateş hamurun ve etin içinden geçerek kemiğe ulaşır. Ancak aşağı yöndeki i'timâdı sona erdiğinde ateş mekânına dönmek için yukarı yönde doğal hareketine (ulvî lâzım ítimâd) başlar. Bu arada kendisiyle birlikte eti ve kemiği de yukarı kaldırır. Bu durum, 1slak toprağa güneşin vurmasına benzer. Güneş ışınları yerin derinliklerine uzun süre nüfuz ettikten sonra, ışınların i'timâdı yukarıya doğru olduğu için, onlarla birlikte topraktaki buhar da havaya yükselir. Ayrıca Basra ekolü, hacamat işleminde dile getirdiği delilin bu örnek için de geçerli olduğunu savunur. Eğer hamur, kömür ve fincan bir kayanın üzerine konsa, kayada aynı etkiyi meydana getirmesi mümkün olmaz. Çünkü hava kaya parçaları arasına karışmaz. Bu nedenle de kayanın yukarı çekilmesi mümkün olmaz. ${ }^{120}$

\subsubsection{Su Saati Deneyleri}

Hem zamanı ölçmek hem de sıvı taşımak için kullanılan su saatlerinin geniş bir gövdesi, dibinde küçük bir deliği ve ağzı başparmakla kapatılabilecek dar bir boynu 
vardır, suyla doldurulup ağzı başparmakla kapatıldığında su içine hapsolur ve akmaz. Ancak ağzı açıldığında alttaki delikten su akmaya başlar. Bu özelliğinden dolayı su saatlerine Yunancada sıvı hırsızı anlamına gelen klepsudra (clepsydra), Arapçada da bunun çevirisi olan serrâkâtü'l-mâ denmiştir. ${ }^{121}$ Su saatini, ilk olarak Aristoteles Antik filozofların yerin durağanlığını açıklamak üzere başvurduğu bir örnek olarak zikretmekte, ancak detaylı bilgi vermemektedir. ${ }^{122}$ Simplicius ise su saatlerinin (hudrarpax) yapısını tarif etmekte ve deneyin detaylarını vermektedir. Ona göre su saati havası alınmadan suya daldırılırsa içine su girmez. Ancak içindeki hava emildiğinde su girişi mümkün olur. Saatin içine bir kez su girdiğinde ise üstteki delikten parmak çekilip, hava girişine izin verilmediği sürece suyun dışarı çıkması mümkün olmaz. ${ }^{123}$ Bu örneği Philoponus da zikretmektedir. Ona göre suyun tabiatının aksine delikten çıkmaması, dışarıdaki havanın direncinden dolayıdır. Su saatinin deliği ince olduğundan suyun tabiatı ile hava direnci denk kalır ve su ile hava karşılıklı yer değiştiremez. Böylece su aletin içinde hareketsiz kalır. ${ }^{124}$

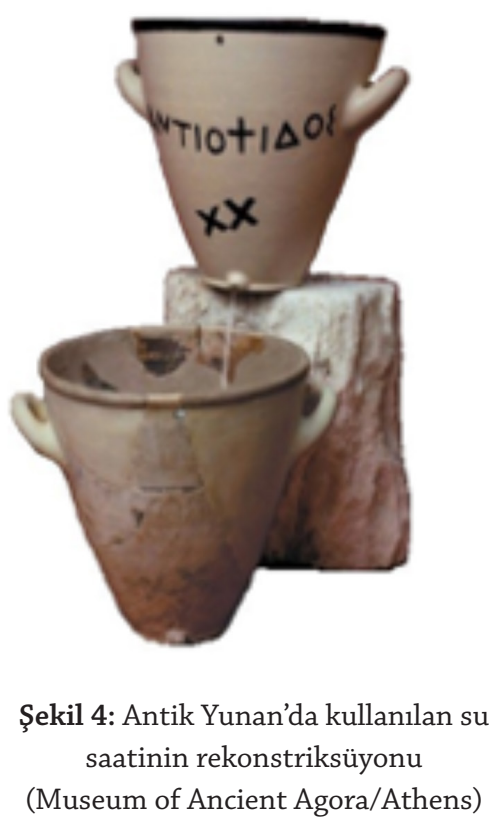

121

Grant, Much Ado About Nothing, 83.

Aristoteles, Gökyüzü Üzerine, 294b 17-21.

Philoponus, Corollary on Void, 569, 18.

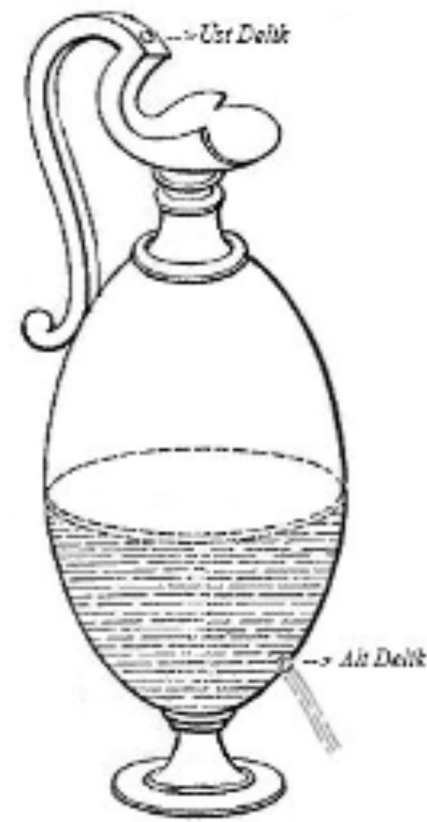

(Hero of Alexswaris Tho PMawames. 22)

Şekil 5: Su saati/klepsudra Simplicius'un zikrettiği bu iki olgu yeryüzünün, altındaki havadan dolayı sabit durduğunu ispat etmek
için örnek verilmiştir. Bkz. Simplicius, On Aristotle on the Void, çev. P. Lettinck ve J.O. Urmson (Londra:
Bloomsbury, 2013), 647, 1/24-30. 
Bağdat ekolüne göre su saatinin içi suyla doldurulup ağzı parmakla kapatıldığında, dibinde küçük bir delik bulunmasına rağmen içinden dışarıya su akışı olmaz. Suyun akışkanlığına ve dökülme özelliğine rağmen delikten akmaması suyla yer değiştirecek havanın olmamasından kaynaklanmaktadır. Ancak parmak ağızdan çekildiğinde su havayla yer değiştirmek suretiyle kaptan dişarı akmaya başlar. ${ }^{125}$ Ka'bî, aynı örneği Makâlât'inda su saati yerine koni şeklinde bir kap kullanarak zikretmektedir. ${ }^{126} \mathrm{Su}$ saati örneğini İbn Hazm da vermekte ve buna idrar yolları tıkalı olanları tedavi etmekte kullanılan bir aleti eklemektedir. ${ }^{127}$ Cürcânî ise, boşluk karşıtlarının aynı olguyu tasvir eden zürrâka isimli bir aletten daha söz ettiklerini aktarmaktadır. Zürrâka bakırdan yapılan bir borudur. Bu borunun yarısı ince yapılı ve içi son derece dardır. Diğer yarısı da kalın ve içi geniştir. Borunun geniş kısmını kapatacak şekilde bir ahşap çubuk hazırlandıktan sonra borunun içi suyla doldurulup geniş bölümün giriş kısmı ahşap çubukla kapatıldığında, ince kısmın ağzı açık olduğu halde, borudan hiç su çıkmadığı görülür. Ancak ahşap çubuk boruya sokulduğunda, boruya girdiği miktar kadar su ince kısımdan tazyikle çıkar. Eğer boruda boşluk olsaydı su, ahşabın boruya girmesiyle önce bu boşlukları doldururdu. Ancak boruya giren ahşap kadar suyun dışarı çıkması boruda hiç boşluğun olmadığını göstermektedir. Yine ahşap çubuk, ince kısmın ağzına kadar girse ve daha sonra geri çekilse bu kez ince kısımdaki su geniş kısma doğru çekilir. Bu da yine boşluğun imkânsızlığı nedeniyledir. ${ }^{128}$

Basra ekolüne göre su saatinin altındaki küçük delikten suyun akmamasının nedeni, dışarıdaki havanın suyun akmasına engel olmasıdır. Çünkü su saatinin üst tarafı kapalı olduğu için suya yeterli miktarda hava karışmamaktadır. Alttaki delik çok küçük olduğu için buradan suya yeterince hava karışmaz. Ancak parmak ağızdan çekildiğinde yeterince hava girer ve bunun suya karışmasıyla akışı engelleyen hava direnci kırılır. Böylece su akmaya başlar. Aynı şekilde alttaki deliğin genişletilmesi durumunda da yeterince hava girer ve su akmaya başlar. Eğer Bağdat ekolü haklı olsaydı alttaki delik genişletildiği halde suyun akmaması gerekirdi. Öte yandan su saatine su yerine cıva konulduğunda, cıva hava veya başka bir şeyle yer değiştirmeye ihtiyaç duymayacak ve parmak ağızdan kaldırılmasa bile alttaki delikten akacaktır. ${ }^{129}$

126 Ka'bî, Kitâbu'l-Makâlât, 483.

127 Bkz. Ebû Muhammed İbn Hazm, el-Fasl fi'l-milel ve'l-ehvâ ve’n-nihal (İstanbul: YEK Yayınları, 2017), III, 818.

128 Îcî, el-Mevâkıf, 120; Cürcânî, Şerhu'l-Mevâkıf, II, 195-7; Bu örneğe Pines da temas etmektedir. Bkz. Shlomo Pines, İslam Atomculuğu, çev. Osman Demir (İstanbul: Klasik Yayınları, 2018), 131-32. 
Bu örneklerde suyun akmamasının boşluğun varlığı ve yokluğuyla ilgili olmadığı, bunun asıl nedeninin açık hava basıncı olduğu açıktır. ${ }^{130}$ Ancak o dönemde atmosferin açık hava basıncına sahip olduğuna ilişkin herhangi bir malumat bulunmamaktaydı. Buna rağmen Basra ekolünün, küçük delikten suyun çıkmasına havanın engel olduğunu açık bir şekilde belirtmesi, suyun içindeki hava miktarının onun akmasına engel olan hava basıncından az olduğu gerekçesiyle akmadığı düşüncesine sahip olduklarını göstermektedir. Eğer saatin ağzı açılır veya alttaki delik büyütülürse içeri giren hava miktarı artacak ve suyun akmasına engel olan hava basıncını yenmesi mümkün olacaktır. ${ }^{131}$ Burada ilginç olan husus suyun dışarıdaki havanın basıncını tek başına yenemeyeceğini, ancak içine hava karıştığı zaman yenebileceğini düşünmeleridir.

\subsubsection{Testi deneyi}

Bağdat ekolü testi deneyini günlük hayattaki basit bir gözleme dayandırmaktadır. Buna göre bir testinin içindeki su dondurulursa testi çatlar ve kırılır. Ekole göre bunun nedeni, donduğu zaman suyun cüzlerinin bir araya toplanarak büzülmesidir. Bu durumda testi ile donan su arasına girecek bir şeye ihtiyaç duyulur. Eğer testi kırılmasa su ile testi arasında bir boşluk oluşacaktı. Ancak âlemde boşluk imkânsız olduğundan testiye hava girebilmesi için testi çatlar. ${ }^{132}$

Basra ekolü bu örnekte suyun donma esnasında büzüldüğü tezinin ileri sürülemeyeceğini belirtir. Zira boşluğu reddedenler, suyun sıvı halde iken de katı halde iken de cüzleri arasında boşluk olduğunu kabul etmezler. Bu nedenle büzülmeyi savunmaları da mümkün değildir. Basra ekolüne göre bu olayda testinin kırılmasının nedeni donan suyun büzülmesi değil, aksine suyun donmasıyla birlikte testinin çeperlerine uyguladığı i'timâdın (basıncın) artmasıdır. Bu basınç belli bir seviyeye ulaşınca testinin kırılmasıyla sonuçlanır. Ancak bu durum cam ve toprak gibi nesneler için geçerlidir, demir gibi sert veya daha kalın malzemelerden yapılmış nesneler için geçerli değildir. Zira donmuş su bunları çatlatacak kadar basınç kuvveti uygulayamaz. Nitekim suyu bir testi yerine demirden bir küpe koysak ve içindeki suyu dondursak, küpte bir kırılma ve çatlamaya neden olmaz. ${ }^{133}$

Bu örnekte Bağdat ekolü açık bir şekilde yanılmıştır. Çünkü testinin içinde donan suyun testiyi çatlatma nedeni hacminin küçülmesi değil, tam tersine hacmindeki

Bkz. "Atmosferic Pressure”, Encyclopedia Britannica, ttps://www.britannica.com/science/atmospheric-pressure (09 Mayıs 2020)

131 Dhanani, The Physical Theory of Kalām, 79.

132 İbn Metteveyh, et-Tezkire, 123; Nîsâbûrî, el-Mesâil, 55.

133 İbn Metteveyh, et-Tezkire, 123; Nîsâbûrî, el-Mesâil, 55. 
artıştır. Basra ekolünün donan suyun testiye uygulayacağı basıncın artacağı tezi de isabetlidir. Ancak su, diğer bütün akışkanların aksine +4 derece dondurulduğunda hacmi büyüyen tek maddedir. ${ }^{134}$ Yani aynı deney başka bir sıvıyla veya genleşme katsayısı büyük bir kap kullanılarak yapılsa, kap patlamaz. Dolayısıyla sadece suya özgü bir olayı genele yaymak ve buradan genel bir sonuca ulaşmak isabetli değildir. ${ }^{135}$

\subsubsection{Kırba Deneyleri}

Bu deneyin iki farklı versiyonu bulunmaktadır ve her ikisi de Basra ekolü tarafından boşluk lehine ileri sürülmüştür. Delilin birinci versiyonu içi havayla dolu bir kırbaya iğne batırılarak yapılmaktadır. Buna göre iğnenin kırbayı delmesi, havayla dolu olsa bile onda boşluğun olduğunu göstermektedir. Havayla dolu olduğu halde kırbada hiç boşluk olmasaydı iğnenin girmesi mümkün olamazdı. Bunun reddi ya havanın ve iğnenin aynı mekânı birlikte işgal ettiğini (yani tedâhül düşüncesini kabul etmeyi gerektirir -ki bunu Bağdat ekolü de reddetmektedir) ya da iğne batırıldığı anda kırbadan bir miktar havanın çıktığını kabul etmek gerekir. Ancak bu durumda da Basra ekolünün karşılıklı eş zamanlı yer değiştirme anlayışına yönelttiği eleştiriler geçerliolur. ${ }^{136}$

Burada Basra ekolünün gayesi, hareketin eş zamanlı olarak karşılıklı yer değiştirmeyle gerçekleştiği tezini çürütmektir. Onlara göre kırba deneyinde iğne kırbaya girdiği halde kırbadan hava çıkmaması, bu tezin geçersizliğini göstermektedir. Boşluğu reddedenler, bunun aksini iddia etmeleri halinde tedâhül düşüncesini kabul etmek durumunda kalır. Ancak tedâhül fikrini, kümün-zuhûr teorisini kabul eden Nazzâm ve Câhız dışında hiçbir kelâmcı benimsemez. Ayrıca bu delil, boşluğu reddedenlerin, havanın elastiki bir yapıda olduğu ve içine başka bir cisim girdiğinde sıkılaşabileceği argümanına bir yanıt vermemektedir. Bunun yerine onlar hava gibi diğer bazı nesnelerin genleşmesi veya büzülmesini içinde boşluk bulunduğuna delil getirmektedirler. Boşluk karşıtlarının ise, cisimlerin aralarında hiçbir boşluk olmadan birleştiklerini ileri sürdüklerinden dolayı, genleşme ve büzülmeyi savunamayacaklarını düşünmektedirler.

Delilin ikinci versiyonu kırbada boşluk oluşturmaya yöneliktir. Buna göre içi havayla dolu bir kırbanın içindeki hava güç kullanılarak tümüyle boşaltılır. Böylece

134 Bkz. Emiliano Brini vd., "How Water's Properties Are Encoded in Its Molecular Structure and Energies", Chemical Reviews, https://pubs.acs.org/doi/10.1021/acs.chemrev.7b00259 (08 May1s 2020)

135 Hatice Arpaguş, "Bağdat Mu'tezile Ekolü: Ka'bî Örneği”, İslâm Medeniyetinde Bağdat Uluslararası Sempozyumu (İstanbul, 2008), 175.

136 İbn Metteveyh, et-Tezkire, 117; Nîsâbûrî, el-Mesâil, 49. 
kırbanın iki kenarındaki deri birbirine yapışır. Daha sonra içine tekrar hava girmesin diye ağzı sıkıca kapatılır. Sonrasında kuvvet uygulamak suretiyle yapışık iki kenar birbirinden çekip ayrılır. Bu durumda iki deri birbirinden ayrılır ve kırbanın içinde bir boşluk meydana gelir. Burada derinin gözeneklerinden hava girdiği, bu nedenle kırbada boşluk oluştuğu söylenemez. Eğer bu mümkün olsaydı havası boşaltılmış bir kırbanın bir süre sonra kendiliğinden havayla dolması veya şişirilen kırbanın da bir süre sonra boşalması gerekirdi. Ancak kırbanın havayla şişirilip ağzı kapatıldıktan sonra aynı şekilde kalmaya devam etmesi bu itirazı geçersiz kılmaktadır. ${ }^{137}$

Benzer bir örneği Lucretius boşluğun varlığını ispat için kullanmıştır. Buna göre geniş yüzeyleri birbirine yapışık olan iki cisim aniden birbirinden ayrılırsa, hava tarafından işgal edilinceye kadar aralarında bir boşluk ortaya çıkacaktır. Hava hızlı yayılma özelliğine sahip olsa da ortaya çıkan büyük boşluğu bir anda dolduramaz. Dolayısıyla iki cisim arasında bir an için bile olsa bir boşluk/yokluk meydana gelecektir. ${ }^{138}$ Basra ekolünün ise, bu örneği biraz daha geliştirdiği ve daha güçlü bir forma kavuşturduğu görülmektedir. Çünkü kenarları dikişli, ağzı kapalı bir kırbada yaratılan boşluk daha kalıcı olmakta ve gözlem ile de bu durumun tespiti kolaylaşmaktadır. Ancak kenarları açık iki düz yüzeyde bu deneyin yapılması, oluşan boşluğa aniden hava dolacağı için gözlem ile tespiti güçleştirmektedir.

\subsubsection{Kuyu Deneyi}

Ebû Hâşim'in geliştirdiği bu delile göre derin kuyuların diplerine hava ulaşmadığı için burada hiçbir canlı yaşayamaz. Bir insan buraya inecek olsa ölür, aynı şekilde bir kandil/mum kuyunun dibine indirildiğinde söner. Bu durumda burada boşluğun varlığını kabul etmek gerekir. ${ }^{139}$ Ancak İbn Metteveyh ve Nîsâbûrî delilin bu haliyle zayıf ve güvenilmez olduğunu belirtirler. Onlara göre burada canlı yaşayamamasının nedeninin havanın yokluğu değil, buradaki havanın yoğun (kesîf) olması olduğu söylenebilir. Zira canlılar nefes alabilmek için ince (rakîk/latîf) havaya ihtiyaç duyarlar. Burada havanın kendisi değil, bu nitelikleri bulunmamaktadır. Bu nedenle buraya inen canlilar hayatta kalamazlar. ${ }^{140}$

Bağdat ekolünün bu delile cevap verdiğine ilişkin bir bilgimiz bulunmamaktadır. Belki de ekolün kendi içerisinden yöneltilen eleştiriler bu delili geçersiz kıldığı için buna gerek duymamış olabilirler. 


\section{Sonuç}

Kelâmda boşluk tartışmaları atomculuk doktrininin İslam dünyasına girmesiyle başlamış ve boşluğa dair argümanlar erken sayılabilecek bir dönemde, III/IX. yüzyıldan itibaren entelektüel çevrelerdeki yerini almıştır. Şüphesiz bunda kelâmcıların felsefî gelenekteki tartışmalardan haberdar olması etkili olmuştur. Ancak atomculuğu kabul ettiği halde boşluğu reddeden kelâmcıların varlığı ve atomculukla boşluk fikrini uzlaştırmadaki başarıları, onların Antik Yunan'ın felsefî mirasına orijinal katkılar yaptıklarını, tekrar ve taklidin ötesinde bu argümanları dönüştürüp temellük ederek kendi inançlarıyla uyumlu hale getirdiklerini göstermektedir.

Âlem-dışı/ekstra-kozmik boşluk konusundaki tartışmaların yoktan yaratma, ezelîlik, sonsuzluk ve çoklu evrenler gibi daha çok metafizik bağlamlarda seyrettiği görülmektedir. Bu bağlamda Basra ekolü, âlemin bütünüyle melâ/doluluk olduğu şeklindeki bir anlayışta ilahî yaratmanın bütünüyle tamamlanmış olacağını düşünerek, yoktan yaratılmış, hâdis ve sonlu/sınırlı bir âlem anlayışını temellendirmek için âlem-dışı boşluğun varlığını savunmuştur. Bağdat ekolü ise bu tarz bir boşluğu görmeye, idrak etmeye ve ölçüme konu olmadığ1 gerekçesiyle reddetmiştir. Esasında boşluk yanlısı kelâmcılar da bunu yokluk olarak düşündükleri için, boşluk karşıtlarıyla aynı şeyi söylemiş olmaktadır. Bundan dolayı âlem-içi boşluğu savunan bazı kelâmcıların âlemin ötesine elin uzatılamayacağını söylemeleri çok şaşırtıcı değildir. Öte yandan âlem-dışı boşluğun reddinde kelâmcıların ezelîlik, sonsuzluk ve teselsül gibi fikirlerden kaçınma reflekslerinin etkili olduğu da göz önünde bulundurulmalıdır.

Kelâmcılar arasında asıl tartışmalar âlem-içi/inter-kozmik boşluk konusunda yaşanmıştır. Ortaya konan delillere ve bunlara verilen yanıtlara bakıldığında, bu tartışmalarda bazı teorik ve düşünsel argümanlar kullanılmakla birlikte, deneysel argümanların daha fazla ön plana çıtı̆̆ı görülmektedir. Bu delillere ilişkin bir değerlendirme yapıldığında ise, boşluk yanlısı teorik argümanlardan en güçlü olanın "hareket delili", boşluk karşıtı en güçlü delilin ise "ölçme ve idrak delili" olduğu rahatlıkla söylenebilir. Ancak bu delillere verilen yanıtlar iki taraf açısından da tatmin edici olmamıştır. Zira ne Bağdat ekolü boşluk olmadan hareketin nasıl gerçekleştiğini ne de Basra ekolü yokluk olarak kabul edilen bir boşluğun nasıl idrak ve ölçüme konu olabildiğini tam olarak izah edebilmiştir. Deneysel argümanların ise daha çok Bağdat ekolü tarafından kullanıldığını, bunların da büyük ölçüde Antik dönem mekanik eserlerine ve Aristoteles şârihlerine dayandığını söylemek mümkündür. Benzer şekilde Basra ekolünün de bunlara cevap verirken Yunan atomculuğundan istifade ettiği anlaşılmaktadır. Ancak bu durum ortaya konan delillerin bütünüyle taklit edildiği anlamına gelmemektedir. Zira iki ekolün de bazı yeni deliller ortaya koyduğu, bazı delilleri geliştirdiği, bazılarını ise sosyo-kültürel duruma uygun örnek- 
lerle yeniden formüle ettiği görülmektedir. Örneğin Bağdat ekolünün kırık-çıkıkçı ve hacamat aleti deneyleri, diğerleriyle aynı ilkeye dayanmakla birlikte orijinaldir. Testideki suyun dondurulması deneyi de orijinal, fakat hatalıdır. Basra ekolünün düşünce deneyleri, kabarcık delili, kırba deneyinin ilk versiyonu ve Nîsâbûrînin kâğıt deneyi bütünüyle orijinaldir. Kuyu deneyi de orijinal, fakat hatalıdır. Hareket ve kırbada boşluk oluşturma delilleri ise Yunan atomculuğuna dayanmakla birlikte önemli ölçüde geliştirilmiş ve güçlendirilmiştir.

\section{Kaynakça}

el-Âmidî, Seyfeddin, Ebkârü'l-efkâr fî usûli'd-dîn, III, Kahire: Dâru'l-Kütüb, 2004.

Aristoteles, Fizik, çev. Saffet Babür, İstanbul: Yapı Kredi Yayınları, 2005.

------, Gökyüzü Üzerine, çev. Saffet Babür, Ankara: Dost Kitabevi, 1997.

------, Metafizik, çev. Ahmet Arslan, İstanbul: Sosyal Yayınları, 1996.

Arpaguş, Hatice, “Bağdat Mu'tezile Ekolü: Ka'bî Örneği”, İslam Medeniyetinde Bağdat Sempozyumu, 157-85, İstanbul, 2008.

Arslan, Ahmet, İlkçağ Felsefe Tarihi I: Sokrates Öncesi Yunan Felsefesi, İstanbul: İstanbul Bilgi Üniversitesi Yayınları, 2006.

Atay, Hüseyin, Farabi ve İbn Sina’ya Göre Yaratma, Ankara: Ankara Üniversitesi Basımevi, 1974.

"Atmosferic Pressure", Encyclopedia Britannica, https://www.britannica.com/science/atmospheric-pressure (09 Mayıs 2020).

el-Bağdâdî, Abdülkâhir, Usûlü'd-dîn, Beyrut: Dâru'l-Kütübi'l-İlmiyye, 2002.

Bulgen, Mehmet, "al-Māturīdī and Atomism", Ulum: Journal of Religious Inquiries II/2 (2019): 223-64.

------, Kelâm Atomculuğu ve Modern Kozmoloji, İstanbul: TDV Yayınları, 2015.

------, Klasik İslam Düşüncesinde Atomculuk Eleştirileri, İstanbul: İFAV Yayınları, 2017.

Cansız, Hasan, "Rü’yetullah Meselesi Çerçevesinde Kelam-Bilim İlişkisi”, Doktora tezi, Necmettin Erbakan Üniversitesi, 2019.

Cürcânî, Seyyid Şerif, et-Ta'rifât, Beyrut: Mektebetü Lübnan, 1985.

------, Şerhu'l-Mevâkıf: Mevâkıf Şerhi, çev. Ömer Türker, İstanbul: YEK Yayınları, 2015.

el-Cüveynî, İmâmü'l-Haremeyn, eş-Şâmil fî usûli'd-dîn, İskenderiye, 1969.

Denkel, Arda, İlkçağ’da Doğa Felsefeleri, 2. baskı, Ankara: Doruk Yayınları, 2011.

Dhanani, Alnoor, The Physical Theory of Kalām, Leiden: E.J. Brill, 1994.

Emiliano Brini vd. "How Water's Properties Are Encoded in Its Molecular Structure and Energies", Chemical Reviews, https://pubs.acs.org/doi/10.1021/acs.chemrev.7b00259 (08 May1s 2020)

Erdemci, Cemalettin, Kelam Kozmolojisine Giriş, Ankara: Araştırma Yayınları, 2007.

Erdoğan, Ömer Faruk, "Fârâbî ve İbn Sînâ Felsefesinde Boşluk/Halâ Kavramı”, İslâmî Araştırmalar 30/1 (2019): 98-111. 
el-Eş‘arî, Ebü'l-Hasan, Makâlâtü'l-İslâmiyyîn ve ihtilâfi'l-musallîn, Kahire: Mektebetü’n-Nahdiyyeti'l-Misriyye, 1955.

el-Fârâbî, Ebû Nasr, Fi'l-Halâ, Ankara: TTK Basımevi, 1985.

Grant, Edward, Much Ado About Nothing, Londra: Cambridge University Press, 1981.

Hero of Alexandria, The Pneumatics, çev. B. Woodcroft, Londra, 1951.

Hesse, Mary, "Vacuum and Void", The Encyclopedia of Philosophy, ed. Paul Edwards, VIII, 217-8, New York: Macmillan, 1967.

İbn Fûrek, Ebû Bekr, Mücerredü Makâlâti’̧̧-Şeyh Ebi'l-Hasan el-Eş'arî, Beyrut: Dâru'l-Meşrık, 1986.

İbn Haldûn, Mukaddime, Dimaşk, 2004.

İbn Hazm, Ebû Muhammed, el-Fasl fi'l-milel ve'l-ehvâ ve'n-nihal, İstanbul: YEK Yayınları, 2017.

İbn Manzûr, Lisânü'l-Arab, Kahire: Dâru'l-Meârif, t.y.

İbn Metteveyh, et-Tezkire fî ahkâmi'l-cevâhir ve'l-a'râz, Kahire: Dâru's-Sekâfe, 1975.

İbn Meymûn, Delâletü'l-hâirîn, Kahire: Mektebetü's-Sekâfeti'd-Dîniyye, t.y.

İbn Rüşd, Ebü'l-Velîd, el-Keşfan menâhici'l-edille, Beyrut: Merkezü Dirâsâti'l-Vahdeti'l-Arabiyye, 1998. İbn Sînâ, Uyûnül-hikme, Beyrut: Dâru'l-Kalem, 1980.

------, Kitâbu'ş-Şifâ: Fizik, çev. Muhittin Macit ve Ferruh Özpilavcı, İstanbul: Litera Yayınları, 2004.

------, Kitâbu'l-Hudûd, ed. A. M. Goichon, De L'institut Français, 1963.

el-Îcî, Adudüddin, el-Mevâkıff fì ilmi'l-kelâm, Beyrut: Alemü'l-Kütüb, t.y.

el-Ka'bî, Ebü'l-Kâsım el-Belhî, Kitâbu’l-Makâlât, İstanbul: KURAMER Yayınları, 2018.

Kandemir, Ahmet Mekin, Mútezilî Düşüncede Tabiat ve Nedensellik, İstanbul: Endülüs Yayınları, 2019.

Kindî, “ìlk Felsefe Üzerine”, Kindî: Felsefî Risâleler, Mahmut Kaya, İstanbul: Klasik Yayınları, 2014.

Kutluer, İlhan, Akıl ve İtikad, İstanbul: İz Yayıncılık, 1998.

Long, A. A. ve D. N. Sedley, The Hellenistic Philosophers I: Translations of the Principal Sources, with Philosophical Commentary, Londra: Cambridge University Press, 1987.

el-Mâtürîdî, Ebû Mansûr, Kitâbu't-Tevhîd, çev. Bekir Topaloğlu, Ankara: TDV Yayınları, 2003.

en-Nesefî, Ebü’l-Muîn, Tebsiratü'l-edille fí usûli'd-dîn, I, Ankara: DİB Yayınları, 2004.

en-Nîsâbûrî, Ebû Reşid, el-Mesâil fi'l-hilâfbeyne'l-Basriyyîn ve'l-Bağdâdiyyîn, Beyrut: Ma'hedü'l-İnmâi'l-Arabî, 1979.

el-Pezdevî, Ebü'l-Yüsr, Usûlü'd-dîn, Kahire: Mektebetü'l-Ezheriyye, 2011.

Philoponus, John, Corollary on Void, çev. D. Furley ve C. Wildberg, Londra: Bloomsbury, 1991.

Pines, Shlomo, İslam Atomculuğu, çev. Osman Demir, İstanbul: Klasik Yayınları, 2018.

Platon, Timaios, çev. Erol Günel ve Lütfi Ay, İstanbul: Cumhuriyet Yayınları, 2001.

er-Râzî, Fahreddin, el-Erba'în fî usûlidd-dîn. Kahire: Mektebetü'l-Külliyâti'l-Ezheriyye, t.y.

------, el-Metâlibül'-âliye min ilmi'l-ilâhî, V, Beyrut: Dâru'l-Kitâbi'l-Arabî, 1987.

------, Muhassalü efkâri'l-mütekaddimîn ve'l-müteahhirîn mine'l-ulemâ ve'l-hükemâ ve'l-mütekellimîn, Kahire: Mektebetü'l-Külliyâti'l-Ezheriyye, t.y. 
-------, Tefsîru'l-Fahri'r-Râzî, I, Beyrut: Dâru'l-Fikr, 1981.

Ross, David, Aristoteles, İstanbul: Kabalcı Yayınevi, 2011.

Sedley, David, “Two Conceptions of Vacuum”, Phronesis 27/2 (1982): 175-93.

Simplicius, On Aristotle on the Void, çev. P. Lettinck ve J. O. Urmson, Londra: Bloomsbury, 2013.

Sorabji, Richard, Matter, Space and Motion, Londra: Duckworth, 1988.

eş-Şehristânî, Ebü'l-Feth, Nihâyetü'l-ikdâm fî ilmi'l-kelâm, Londra: Oxford Press, 1934.

Şeyh Müfîd, Evâilü'l-makâlât. Beyrut. Dâru'l-Müfîd, 1993.

et-Tehânevî, Muhammed Ali, Keşşâü ıstılâhâti'l-fünûn ve'l-ulûm, Beyrut: Mektebetü Lübnan, 1966.

Thilly, Frank, Felsefenin Öyküsü, çev. İbrahim Şener, I, İstanbul: İzdüşüm Yayınları, 2000.

Weber, Alfred, Felsefe Tarihi, çev. H. Vehbi Eralp, 5. baskı, İstanbul: Sosyal Yayınları, 1998.

Wolfson, H. Austryn, Kelâm Felsefeleri, çev. Kasım Turhan, İstanbul: Kitabevi Yayınları, 2001.

Yıldırım, Ömer, "İslam Düşüncesindeki Yoktan Yaratma ve Kıdem Tartışmaları: Kelâmcılar ve İbn Sînâ Merkezli Bir İnceleme”, KADER Kelâm Araştırmaları 10/2 (2012): 251-74. 